\title{
The Jekyll and Hyde of Cellular Senescence in Cancer
}

\author{
Dilara Demirci ${ }^{1,+}\left(\mathbb{D}\right.$, Bengisu Dayanc ${ }^{1,2,+}$, Fatma Aybuke Mazi ${ }^{1,2}$ and Serif Senturk $1,2, * \mathbb{D}$ \\ 1 Izmir Biomedicine and Genome Center, Izmir 35340, Turkey; dilara.demirci@ibg.edu.tr (D.D.); \\ bengisu.dayanc@msfr.ibg.edu.tr (B.D.); fatmaaybuke.mazi@msfr.ibg.edu.tr (F.A.M.) \\ 2 Izmir International Biomedicine and Genome Institute, Dokuz Eylul University, Izmir 35340, Turkey \\ * Correspondence: serif.senturk@ibg.edu.tr; Tel.: +90-(232)-4126514 \\ + These authors contributed equally to this work.
}

Citation: Demirci, D.; Dayanc, B.; Mazi, F.A.; Senturk, S. The Jekyll and Hyde of Cellular Senescence in Cancer. Cells 2021, 10, 208. https:// doi.org/10.3390/cells10020208

Received: 23 December 2020

Accepted: 17 January 2021

Published: 21 January 2021

Publisher's Note: MDPI stays neutral with regard to jurisdictional claims in published maps and institutional affiliations.

Copyright: (c) 2021 by the authors. Licensee MDPI, Basel, Switzerland. This article is an open access article distributed under the terms and conditions of the Creative Commons Attribution (CC BY) license (https:/ / creativecommons.org/licenses/by/ $4.0 /)$.

\begin{abstract}
Cellular senescence is a state of stable cell cycle arrest that can be triggered in response to various insults and is characterized by distinct morphological hallmarks, gene expression profiles, and the senescence-associated secretory phenotype (SASP). Importantly, cellular senescence is a key component of normal physiology with tumor suppressive functions. In the last few decades, novel cancer treatment strategies exploiting pro-senescence therapies have attracted considerable interest. Recent insight, however, suggests that therapy-induced senescence (TIS) elicits cell-autonomous and non-cell-autonomous implications that potentially entail detrimental consequences, reflecting the Jekyll and Hyde nature of cancer cell senescence. In essence, the undesirable manifestations that generally culminate in inflammation, cancer stemness, senescence reversal, therapy resistance, and disease recurrence are dictated by the persistent accumulation of senescent cells and the SASP. Thus, mitigating these pro-tumorigenic effects by eliminating these cells or inhibiting their SASP production holds great promise for developing innovative therapeutic strategies. In this review, we describe the fundamental aspects and dynamics of cancer cell senescence and summarize the comprehensive research on the adverse outcomes of TIS. Furthermore, we underline the rationale and motivation of emerging senotherapeutic modalities surrounding the removal of senescent cells and the SASP to help maximize the overall efficacy of cancer therapies.
\end{abstract}

Keywords: cancer; cellular senescence; SASP; therapy-induced senescence; senostatic; senolytic

\section{Introduction}

Almost 60 years ago, Hayflick and Moorhead challenged Carrel's original proposition that normal cells have an infinite replication capacity. On that account, Hayflick performed a series of experiments with diploid primary cells derived from various human embryonic tissues. These studies unveiled the fact that normal cells propagated in culture can replicate for a limited and probably predetermined number of generations, after which they undergo an irreversible arrest of cell growth, thus disproving Carrel's theory of cellular immortality $[1,2]$. This phenomenon is now known as the Hayflick limit or, as it will be called herein, replicative senescence [3-6]. Over the course of six decades, cellular senescence has been established as an adaptive stress response mechanism in physiological and pathological processes with both beneficial and detrimental consequences for human health [7-10].

Depending on the cell type and conditions, different subtypes of cellular senescence such as DNA-damage-induced senescence, stress-induced senescence (SIS), and oncogeneinduced senescence (OIS) have been defined [11-13]. Earlier studies have shown that cellular senescence program is a key component of embryonic development and tissue remodeling and may potentially function as a tumor suppressor mechanism against carcinogenesis $[9,14,15]$. Work in recent decades have debated the longstanding fundamental paradigm of senescence irreversibility. In striking contrast to the traditional definition, these research efforts have provided mounting evidence that this complex phenotype is not a static, permanent, and docile state, but rather entails a constantly evolving multi-step process with cell-autonomous 
and non-cell-autonomous implications and often deleterious effects on tissue homeostasis. In the context of cancer therapy, this capacity is primarily due to the fact that senescent cells remain viable and bioactive for long periods of time and eventually resume proliferation while emitting heterotypic signals to their microenvironment [16-19].

The century-old classic novel "The Strange Case of Dr. Jekyll and Mr. Hyde" by Robert Louis Stevenson explores the duality of human nature-specifically, the natural existence of a dual personality, good and evil, in the same individual. Arguably, the balance between good and evil is what makes us human. In some sense, this theme is analogous to the dual nature of cellular senescence, where it can be both beneficial (Jekyll) and detrimental (Hyde). Our objective in this review is to synthesize the recent scientific advances pertaining to the duality of cellular senescence, with a heightened interest in cancer, and to present scientific advances and challenges in exploiting this phenotype in cancer therapies. With this motivation, we first revisit the hallmarks of cellular senescence primarily by stressing the morphological and molecular biomarkers, as well as the regulation and functions of the senescence-associated secretory phenotype (SASP). The key effector mechanisms and different subtypes of cellular senescence are then briefly summarized. Next, we discuss the biological significance of cellular senescence in normal physiology and shift the focus to cancer, referencing the good and evil natures of this phenomenon. From there, we elaborate on the concepts of therapy-induced tumor cell senescence, stemness, and senescence escape. Finally, we accentuate the impact and the rationale of emerging senotherapeutic approaches surrounding the targeting of senescent cells and the SASP to help develop novel cancer treatments.

\section{The Hallmarks and Molecular Mechanisms of Cellular Senescence}

\subsection{Morphological and Molecular Biomarkers of Senescent Cells}

Typically characterized by the inability to replicate their DNA and cellular growth arrest, cultured senescent cells exhibit a series of distinct morphological and chemical hallmarks which distinguish them from proliferating cells. Perhaps the most notable molecular markers are multiple or enlarged nuclei and flattened cytoplasm, an increased number of lysosomes and Golgi apparatus, elevated $\mathrm{pH}$-dependent senescence-associated $\beta$-galactosidase activity (SA- $\beta$-gal), and resistance to apoptosis $[16,20,21]$. Senescent cells are also frequently characterized by impaired nuclear integrity; the formation of persistent nuclear DNA damage foci and DNA-damage response (DDR); deregulated metabolism; protein and lipid damage; global epigenetic changes in their chromatin landscape; the formation of senescence-associated heterochromatin foci (SAHF); and, of course telomere attrition, the hallmark of replicative senescence [12,13,22-24] (Figure 1).

\subsection{The Senescence-Associated Secretory Phenotype (SASP) of Senescent Cells}

A striking feature of virtually all senescent cells is the widespread changes in protein expression that involve a specific signature for secreted molecules, collectively known as the SASP. The SASP consists of a myriad of biologically active soluble and insoluble factors which can be grouped into the following major categories: proinflammatory interleukins and chemokines; growth factors; extracellular matrix proteins and remodeling enzymes; damage-associated molecular patterns; and extracellular vehicles greatly enriched for enzymes, miRNAs, and DNA fragments [25-30]. Recently, Basisty et al. developed a comprehensive and quantitative proteomic atlas that can potentially serve as a reference and guide for the identification of novel soluble (sSASP) and exosome/extracellular vesicle SASP (eSASP) factors. The atlas is currently limited to two distinct cell lines induced to senesce by various stress factors. However, the authors expect the resource to be continuously updated by depositing new SASP profiles derived from different cell types and senescence-inducing conditions [30]. In essence, the abundance and heterogeneous composition of the SASP is context-dependent, partly explaining how the SASP can exert profoundly diverse and sometimes contradictory functions in numerous biological processes such as tissue remodeling, inflammation, and age-related pathologies including cancer [31]. 
(i)

Senescence Insults

(ii)
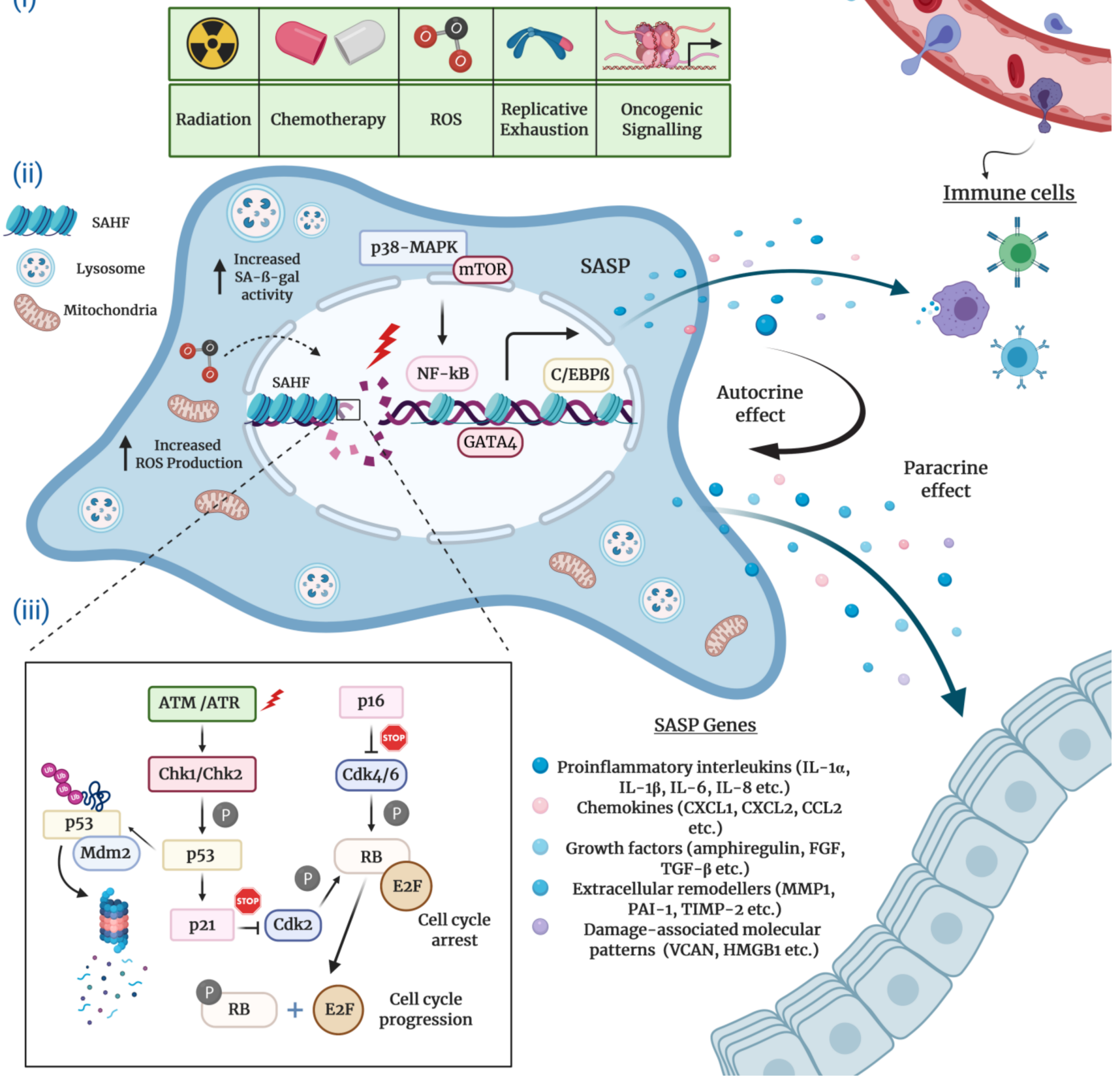

Figure 1. The hallmarks and molecular mechanisms of cellular senescence. The figure summarizes 3 major attributes of cellular senescence. (i) Intrinsic and extrinsic insults causing senescence: The extrinsic factors causing senescence-related cell cycle arrest comprise of radiation and chemotherapy, whereas intrinsic factors harbor increased reactive oxygen species (ROS) accumulation, aberrant oncogene activation, and replicative exhaustion. (ii) Molecular hallmarks of senescent cells and pathways regulating senescence-associated secretory phenotype (SASP) production and immune cell infiltration (recruitment of immune cells to the SASP-rich milieu): SASP expression is predominantly controlled by the p38-MAPK and mTOR pathways and C/EBP $\beta$, GATA4, NF- $\kappa$ B transcription factors. Senescent cells enriched for SASPs disseminate a wide assortment of senescence cues (proinflammatory interleukins, chemokines, growth factors, extracellular remodelers, damage-associated molecular patterns/DAMPs) to the surrounding cells (paracrine effect). At the same time, these cues influence on the senescent cell itself (autocrine effect). Clearance of senescent cells is actualized via immune surveillance mechanisms, and (iii) molecular mechanisms modulating cell cycle arrest: DNA-damage dependent and DNA-damage independent mechanisms regulate the key effector mechanisms $\mathrm{p} 53 / \mathrm{p} 21^{\mathrm{Cip} 1}$ and $\mathrm{pRb} / \mathrm{p} 16^{\text {Ink4a }}$ to initiate and maintain cellular senescence. 
The SASP regulation in senescent cells has been the subject of numerous studies. The findings collected in these studies substantiate the notion that the SASP production is coordinated by a complex network of signaling cascades that involve to a large extent transcriptional but also post-transcriptional mechanisms (Figure 1). Stress-inducible kinase p38 mitogen-activated protein kinase (p38-MAPK), mammalian target of rapamycin (mTOR), cytosolic DNA-sensing cyclic GMP-AMP synthase (cGAS)-stimulator of interferon genes (STING), the Ataxia telangiectasia mutated (ATM)/ATM- and RAD-3 related (ATR)-activated IKB kinase (IKK)/NEMO complex, and the GATA binding protein 4 (GATA4) axis constitute the most prominent upstream regulators of the pro-inflammatory senescence phenotype [31-36]. Upon stimulation by stress conditions, these interactive signaling pathways converge towards the activation of a transcriptional program managed by the nuclear factor kappa B (NF-kB) and the CCAAT-enhancer binding protein $\beta(\mathrm{C} / \mathrm{EBP} \beta)$, the core effectors that initiate and maintain SASP gene expression $[31,37,38]$. A number of studies suggest that the Janus kinase-signal transducer and activator of transcription (JAK/STAT) and NOTCH pathways also play a crucial role in the transcriptional regulation of SASP components through C/EBP $\beta$ [39-41].

The DDR signaling pathway is a critical mediator of the SASP. Available research indicates that the direct activation of ATM/ATR protein kinases in response to persistent DNA damage inhibits the autophagic degradation of GATA4, which, in turn, activates NF- $\mathrm{KB}$ to initiate and maintain the SASP network [42,43]. Differently, several reports describe the DNA damage-independent control of the SASP induction, which, in general, involves the p38-MAPK-mediated activation of NF-кB [32,44-47]. Intriguingly, mitochondrial dysfunction-associated senescence (MiDAS) is a distinct form of DDR-independent cellular senescence wherein the cells undergoing MiDAS display a unique SASP profile dictated by AMP-activated protein kinase (AMPK)-mediated p53 activation [47].

Epigenetic mechanisms are also pronounced in the modulation of cellular senescence and SASP constituents. For example, the histone variants macroH2A1 and H2AJ accumulate in human primary lung fibroblasts during OIS and play an important role in the positive and negative regulation of SASP production $[48,49]$. Similarly, epigenetic modifiers including lysine methyltransferase 2A (KMT2A, also known as MLL1), high-mobility group B protein 1 and 2 (HMGB1 and HMGB2), and bromodomain-containing protein 4 (BRD4) modulate the senescence secretome by orchestrating the chromatin landscape around the SASP gene loci [50-53]. Moreover, the downregulation of sirtuin 1 (SIRT1) gene and the enhancer of zeste 2 polycomb repressive complex 2 subunit $(E Z H 2)$ gene in senescent cells positively regulate SASP factors, which are mediated by transcriptomic changes through the post-translational modifications of histones [46,54]. In addition to transcriptional mechanisms, the expression of SASP genes is regulated at the post-transcriptional level. In particular, MAPK-activated protein kinase 2 (MK2), a downstream effector of the p38-MAPK and mTOR pathways, modulates the mRNA stability of a subset of SASP components by means of ARE-mediated decay [55,56].

\subsection{Molecular Mechanisms Underlying Cellular Senescence}

The complex network of molecular events that execute cellular senescence has been extensively reviewed elsewhere $[40,57,58]$. Nonetheless, for the sake of the completeness and consistency of this review, we will mention the critical effector pathways. Many lines of research convincingly attest that the onset and maintenance of permanent senescence arrest is controlled by the $\mathrm{p} 53 / \mathrm{p} 21^{\mathrm{Cip} 1}$ and the retinoblastoma protein $(\mathrm{pRb}) / \mathrm{p} 16^{\text {Ink4a }}$ tumor suppressor pathways (Figure 1). In principle, the activation of either one or both of these crucial pathways can readily induce cellular senescence. Notably, genetic mutations or epigenetic silencing of these pathways obliterates the senescence response in most cell types, occasionally paving the way for cancer initiation and progression [59].

Mechanistically, in its active hypophosphorylated form the $\mathrm{pRb}$ binds to and sequesters E2F family of transcription factors and induces growth arrest in the G1 phase of the cell cycle. To achieve this, pRb suppresses the transcription of several E2F target genes 
encoding a repertoire of essential proteins indispensable for DNA replication and cell cycle, thus blocking the subsequent entry into and progression through the $S$ phase. The regulation of cellular senescence by E2F is often correlated with context-dependent local or global structural epigenetic modifications such as chromatin remodeling and SAHF formation. Consistent with this, the promoters of E2F target genes are enriched for repressive histone modifications (mainly H3K9me3 and H3K27me3) which result in gene expression changes that eventually contribute to the regulation of cellular senescence. Upon phosphorylation by Cyclin D and Cyclin-dependent kinase 4 and 6 (CDK4 and CDK6), a complex that is negatively regulated by the $\mathrm{p} 16^{\text {Ink4a }}$ tumor suppressor protein, $\mathrm{pRb}$ switches to an inactive state and releases E2F, thus stimulating cell cycle progression [60-63].

The p53 transcription factor, the guardian of the genome integrity, plays a pivotal role in the induction and maintenance of cellular senescence. Following exposure to genotoxic or non-genotoxic stress, p53 gets activated and promotes cell cycle arrest via DDR-dependent and DDR-independent mechanisms. The specific activity of p53 is tightly controlled by virtue of positive and negative regulators and post-translational modifications. In response to stress stimuli, p53 is phosphorylated and stabilized by ATM/ATR and Checkpoint kinase 1 and $2(\mathrm{Chk} 1 / 2)$ protein kinases, releasing it from MDM2, an E3 ubiquitin ligase that negatively regulates p53 via ubiquitination and proteasomal degradation. Once activated, p53 selectively increases the transcription of various target genes, in particular p21 ${ }^{\text {Cip1 }}$ (CDKN1A), a potent CDK inhibitor which executes the p53-mediated control of cellular senescence. The p21 ${ }^{\text {Cip } 1}$ protein binds to and inhibits the activity of Cyclin $\mathrm{E} / \mathrm{CDK} 2$ and Cyclin D/CDK4 complexes, thus activating pRb and blocking cell cycle progression [17,64-66]. Finally, yet importantly, depending on the cellular identity and stress factors, antitumor mechanisms coordinated by the p53 and pRb pathways may engage different subtypes of cellular senescence.

\section{The Significance of Cellular Senescence: From Homeostasis to Cancer}

Almost a century ago, Muller and McClintock postulated that telomeres, the specialized structures found at the ends of linear eukaryotic chromosomes, were critically essential for the maintenance of chromosomal stability $[67,68]$. Later, in the 1970s, Olovnikov and Watson speculated independently that the chromosomal ends become shorter with each round of DNA replication [69,70]. Landmark discoveries in the following years have revealed that telomeres protect the chromosomes against degradation and interchromosomal fusions, thus contributing to the maintenance of genome integrity [71-73]. Furthermore, telomeres control the number of successful divisions that a normal cell can undergo before entering permanent growth arrest, the state of replicative senescence. This phenomenon is explained by progressive shortening of telomeres due to decreased or lack of telomerase reverse transcriptase enzyme (TERT) expression or activity [74,75]. Accordingly, the reintroduction of TERT gene into somatic cells promotes bypass of replicative senescence [76,77]. Unlike somatic cells, certain stem cell populations, germ cells, and rapidly dividing cells including cancer cells retain a high telomerase activity. Convincingly, the maintenance of telomere homeostasis via sustained or restored telomerase activity is associated with immortality and thereby considered a hallmark of cancer [78]. Notably, TERT gene amplification, translocations to euchromatic regions, and highly recurrent promoter mutations are the most common mechanisms of telomerase reactivation in cancer [79-83].

Stress-induced senescence (SIS), also known as stress-induced premature senescence, is a global spectrum of acutely evoked growth arrest programs. Functionally, SIS protects the organism from the potentially harmful effects of excessive accumulation of damaged cells in tissues and serves as a cell-intrinsic barrier against preneoplastic transformation. While sharing similar molecular and functional features with replicative senescence, SIS is essentially distinct in the nature of provoking stimuli. Almost any form of cell extrinsic or cell intrinsic stressors other than telomere dysfunction/damage can potentially induce SIS. Triggers include oncogene activation or suppression of tumor suppressor genes, cytokines, mitochondrial dysfunction, reactive oxygen species (ROS), DNA damage or 
nucleotide depletion [84-88]. Spindle stress or nucleolar stress, unfolded protein response and endoplasmic reticulum (ER)-stress, and metabolic and epigenetic alterations are the other well-recognized SIS-inducing stimuli $[16,89,90]$. On the whole, these stress factors directly or indirectly cause damage to biological macromolecules such as nucleic acids, carbohydrates, lipids, and proteins.

Cellular senescence can be divided into two fundamentally different categories according to the functionality and kinetics of the senescence process, a priori the extent and duration of the stimulus $[9,91]$. Acute (transient) cellular senescence, mainly caused by cell-extrinsic factors, often targets a defined group of cells and is generally acknowledged as a beneficial and tightly regulated physiological process in development and tissue injury repair [92,93]. Importantly, acute senescent cells can orchestrate their self-recognition and immune-mediated clearance through effector mechanisms manifested by the SASP factors, further implying that this scheduled or programmed process is temporal [33,94]. By contrast, chronic (persistent) cellular senescence is a non-programmed process with no specific target cell population and has detrimental effects on tissue homeostasis. In many settings, chronic cellular senescence is associated with prolonged exposure to genotoxic stress and progressive macromolecular damage to cellular components $[9,95]$. There are studies which detail that chronic cellular senescence evolves from an acute state, especially when the immune clearance is severely impaired. The vast majority of these reports suggest that the subsequent accumulation of persistent senescent cells amid the secretion of multi-faceted SASP factors is usually harmful and can both aggravate and contribute to age-associated pathologies, including atherosclerosis, renal pathologies, and cancer [96-98]. Taken together, these seemingly contradictory beneficial and detrimental functions make this vital molecular process a double-edged sword with both opportunities and obstacles for therapeutic targeting.

\section{The Implications of Therapy-Induced Senescence in Cancer}

Traditional cancer treatments have relied on genotoxic and cytotoxic therapies such as chemotherapy and radiation therapy or an effective combination of both. These therapies typically provide high enough doses of drugs to induce complete cell death in rapidly dividing cancer cells [99]. Under such circumstances, cytotoxic strategies also cause significant toxicity to normal cells, leading to severe side effects in multiple organ systems [100]. Despite the fact that these interventions deliver therapeutic benefits and overall improvement in survival outcomes, tumors frequently develop resistance and advance to more aggressive primary or metastatic diseases [101-103]. When compared with cytotoxic therapies, cytostatic therapies do not exert direct cytotoxicity but rather aim to slow down or stop the growth of tumor cells $[104,105]$. On the basis of the antitumor activities of senescence process in early-stage premalignant lesions, senescence-inducing strategies have been valued as alternative therapies in the battle against cancer. An effective and promising strategy to induce cytostasis in cancer treatment is therapy-induced senescence (TIS). Aside from their cytotoxic actions, when administered in low doses or intermittent regimens certain conventional therapies display cytostatic activity and promote TIS in human cancer tissues [105-107].

Cisplatin and doxorubicin are the first genotoxic stressors shown to trigger cancer cell senescence $[108,109]$. Similarly, topoisomerase inhibitors, antimetabolites, alkylating agents, and microtubule inhibitors have been reported to induce TIS [110-112]. Interestingly, targeted therapies can also provoke cellular senescence in cancer cells. Research on targeted pro-senescence therapies is specifically concentrated on the reactivation of tumor suppressor pathways (e.g., p53-MDM2 and p53-p21 axis) or the therapeutic targeting of oncoproteins (e.g., Myc), the inhibition of cell cycle machinery (e.g., CDC7, CDK4/6, and PARP), the suppression of cellular pro-survival pathways including receptor tyrosine kinases and their downstream effectors (e.g., PI3K/Akt/mTOR, PTEN, and aurora kinase B), casein kinase 2 (CK2), and epigenetic modulators [113-117]. 
Given these efforts, TIS is considered as a powerful intervention in conventional cancer therapy. However, the strategies exploiting pro-senescence therapies are complicated, the reason being that TIS can be transient and reversible in nature. More importantly, the persistent accumulation of senescent cancer cells and the SASP following TIS are endowed with cell-autonomous and non-cell-autonomous mechanisms which facilitate senescence escape, invasiveness, therapy resistance, and cancer recurrence $[118,119]$. The pioneering study by Elmore et al. discovered that breast cancer cells, acutely exposed to doxorubicin, could evade the stress insult and produce resistant clones that were no longer responsive to senescence-inducing cytotoxic drugs, including the doxorubicin rechallenge. Interestingly, senescence-resistant cells had normal intracellular drug accumulation and functional DDR machinery, and the senescence evasion was coupled to the elevated expression of proliferative cell cycle regulators, in particular Cdc2/CDK1 [120-122]. Similarly, Roberson et al. found that p53-null and p16 $6^{\text {Ink4a }}$-deficient human lung carcinoma cells escape from TIS through the increased expression and phosphorylation of Survivin, a downstream effector of Cdc2/CDK1 survival signal. Moreover, the inhibition of Cdc2 and Survivin activity increases chemotherapy efficiency and reduces tumor recurrence [123]. Another study by Yang et al. revealed that the intermittent administration of chemotherapeutic compounds generates aggressive cell variants that acquire the ability to evade cellular senescence. To that end, lung tumor cells undergoing doxorubicin-induced senescence were then exposed to other stress-inducing cytotoxic agents. Interestingly, cells subjected to sustained selective pressure spontaneously reentered cell cycle and eventually produced senescence revertants with enhanced potential for migration and invasion. Finally, the revertants outcompeted parental counterparts in tumor growth when implanted subcutaneously into nude mice, concluding that aggressive cell variants may emerge as an outcome of chemotherapy [124]. Similarly, the work by Saleh et al. utilized topoisomerase II inhibitors to trigger cellular senescence in lung, colon, and breast cancer cell lines. In support of the previous findings, the live cell tracking of the senescence phenotype with special reporters identified reemerging clones that recovered from cellular senescence and acquired proliferative and tumorigenic potential, strongly suggesting an escape from or reversal of TIS [119].

Recently, a breakthrough study has unveiled a new, yet unexpected, cell-intrinsic relationship between spontaneous escape from TIS and senescence-associated stemness (SAS). This discovery has definitely advanced our understanding on the plasticity of senescent cancer cells and the significance of attacking these cells in cancer therapies. To that end, the authors initially compared the gene expression profiles of doxorubicin-exposed versus untreated lymphomas, specifically senescence-competent primary $\mathrm{E} \mu-M y c$ transgenic $B c l 2$-overexpressing lymphomas (dubbed as $\mathrm{E} \mu-\mathrm{Myc} ; \mathrm{Bcl}$ ) and senescence-incompetent Suv39h1-deficient $\mathrm{E} \mu-M y c ; B c l 2$ lymphomas. Transcriptome data uncovered that the key signaling components of TIS essentially overlap with stemness pathways. Importantly, senescence-competent cells were enriched for the adult tissue stem-cell gene signature, suggesting that senescent cancer cells acquire phenotypic and functional features of stem cells. Furthermore, the authors found that turning off the expression of Suv39h1 or p53, two critical effectors of senescence, using a tamoxifen-inducible system results in cell cycle progression. Strikingly, the senescence-released lymphoma cells with SAS capacity display markedly higher tumor initiation potential when compared to never senescent lymphomas. Mechanistically, SAS reprogramming in post-senescent cancer cells was strongly attributed to epigenetic mechanisms that enhanced cell-intrinsic Wnt signaling, largely excluding the potential role of non-cell-autonomous mechanisms [125,126]. Together, this study illustrates that TIS can trigger a cell-autonomous and senescence-associated stemness reprogramming in proliferation-arrested cancer cells and those cells that manage to escape from senescence evolve into more aggressive tumor-initiating cells.

Today, there is strong research evidence in support of the notion that the escape from cellular senescence in cancer represents, in principle, a natural phenomenon of reversibility that is not limited to TIS but can occur with other forms of senescence insults. A number of studies have demonstrated that arrested cells can readily escape from OIS by 
mechanisms linked to TERT derepression/reactivation and the inactivation of p53 and pRb pathways [127-129]. Furthermore, unpublished observations from our group suggest that hepatocellular carcinoma (HCC) cells retain the potential to regain proliferative capacity following TGF- $\beta$-mediated prolonged senescence.

\section{Therapeutic Targeting of Senescent Cells and the SASP in Cancer}

As detailed here and elsewhere, the negative implications associated with the prosenescence cancer therapies are generally attributed to the accumulation of senescent cancer cells and their SASP composition and intensity $[130,131]$. In view of that, the number of studies focusing on counterbalancing the potential detrimental effects of such therapies has experienced a significant expansion in recent years. In particular, the regulation and therapeutic targeting of the senescence phenotype and the SASP has become an area of extensive research. Currently, the gold-standard therapeutic approaches to keep these cells under control are (i) boosting immune surveillance mechanisms, (ii) intervening the SASP production and activity through senomorphics, and (iii) the selective elimination of senescent cells with senolytic agents [132-135]. We note that the immune-mediated clearance of senescent cells is beyond the coverage of this review, thus we would like to divert the reader to other reports to comprehend this topic $[31,94,136]$.

\subsection{SASP Activity in Cancer and Anti-SASP Therapies}

One potential mechanism by which senescent cancer cells display both anti- and pro-tumorigenic activities is the Jekyll and Hyde dynamics of the SASP network. From the anti-tumorigenic perspective, the SASP factors may reinforce the cell-intrinsic control and maintenance of the senescence fate and instruct the paracrine transmission of secondary senescence to SASP-receiving premalignant cells. In addition, the non-cell-autonomous SASP can engage immunosurveillance mechanisms and ensure that senescent cancer cells are eliminated from the tumor tissue [26]. Yet, in some contexts, the accumulation of senescent cancer cells, again by virtue of the SASP, is strongly implicated in promoting aggressive cancer cell behaviors and immunoediting [137-140]. Therefore, attenuating the constituents or the regulators/effectors of the SASP, without actually compromising their tumor suppressive functions, embodies a fundamental therapeutic advantage in cancer. On this account, early studies proposed that the SASP can be successfully suppressed by calorierestricting diets, the activators of telomerase and sirtuin family of proteins, broad antiinflammatory agents (e.g., glucocorticoids) as well as the activators of autophagy [141-145]. In contrast, recent studies have encouraged exploiting anti-SASP approaches for more specific targets.

As alluded to earlier, the secretory component of senescent cells is mainly orchestrated by NF- $\mathrm{BB}$ and $\mathrm{C} / \mathrm{EBP} \beta$. These transcription factors are modulated by upstream signaling networks which clearly represent attractive therapeutic targets for senostatic interventions. Senostatics are characterized as the drugs that repress markers or phenotypes of senescent cells without promoting apoptotic cell death. To date, several natural or pharmacological agents have been proposed to effectively blunt these pathways and mitigate the deleterious consequences of pro-tumorigenic SASP factors (Figure 2). 


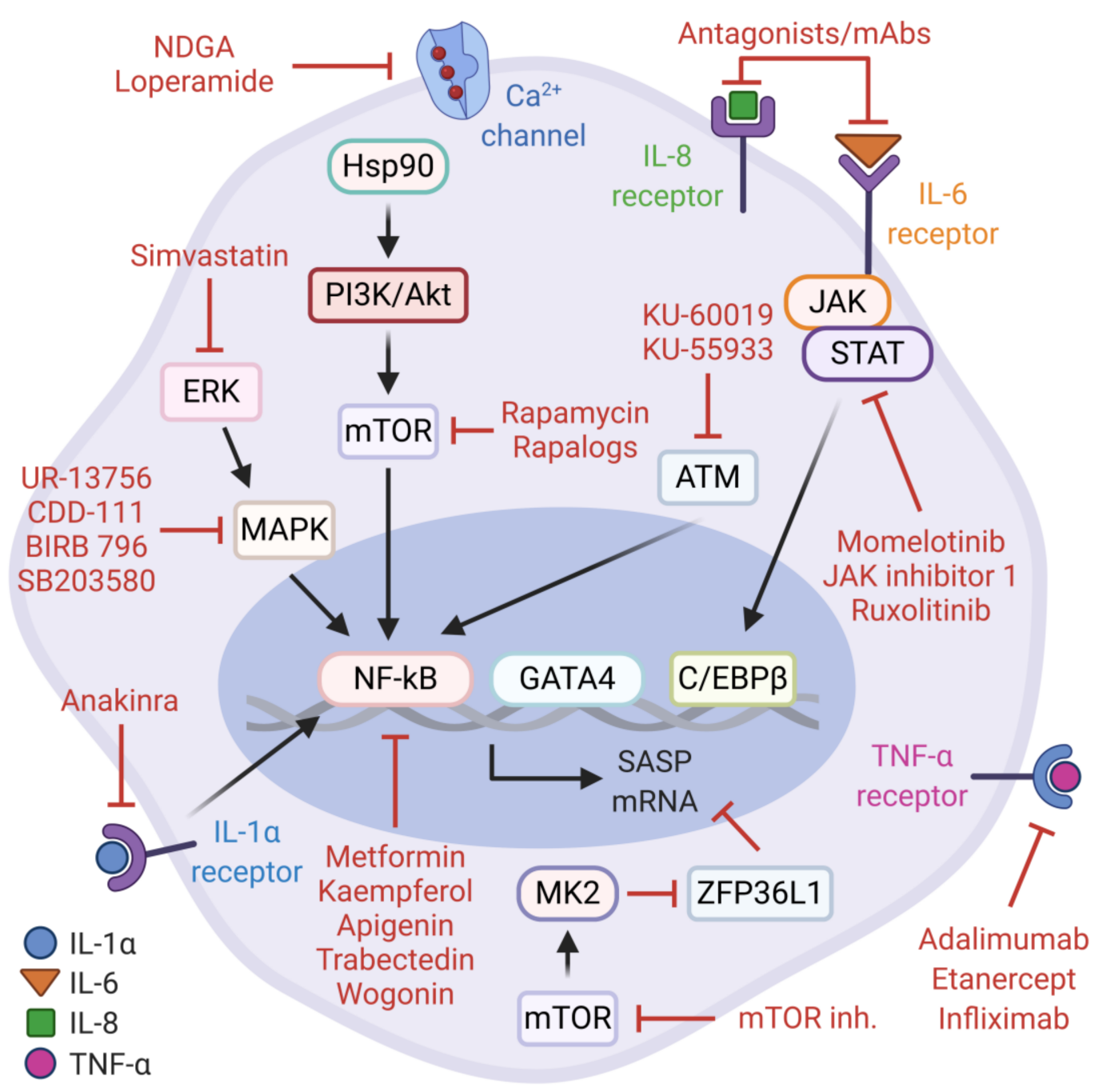

Figure 2. Anti-SASP therapies. Senostatics suppress markers of senescence and blunt SASP production. The main targets include NF- $\mathrm{BB}$ and $\mathrm{C} / \mathrm{EBP} \beta$ transcription factors and their upstream signaling networks. These types of senostatics provide the cell-intrinsic repression of the SASP. Autocrine and paracrine effects of the SASP are prevented by targeting the main components of the SASP, especially IL- $1 \alpha$, IL-6, IL- 8 , and TNF- $\alpha$.

One of these druggable mechanisms is the PI3K/Akt/mTOR pathway. The physiological inhibition of this signaling cascade by rapamycin, a pharmacological mTOR inhibitor, contributes to longevity and delays age-related pathologies in various model organisms [146-149]. In the context of cellular senescence, rapamycin and rapalogs (rapamycin analogs) can attenuate the mTOR-dependent transcriptional activity of NF- $\mathrm{KB}$ and alleviate the synthesis of pro-tumorigenic SASP factors without preventing the senescence arrest. These observations are explained by the translational inhibition and subsequent reduction in cell-surface bound IL- $1 \alpha$, which can suppress the IL- $1 \alpha / \mathrm{NF}-\mathrm{kB}$ positive feedback loop [150]. Consistent with this, Herranz et al. also reported that rapamycin and other mTOR inhibitors (Torin 1 and NVP-BEZ235) can inhibit OIS-mediated SASP gene expression based on the observations that mTOR signaling controls the stability of SASP transcripts via MK2-mediated negative regulation of ZFP36L1, a zinc-finger RNA-binding protein with mRNA decay activity. Furthermore, rapamycin administration in mice with transposon-mediated N-RAS ${ }^{\mathrm{G} 12 \mathrm{~V}}$ expression in hepatocytes demonstrates potent activity against pro-inflammatory SASP during liver cancer initiation [56]. Together, these findings may likely explain the beneficial effects of rapamycin in age-related pathologies and extend its therapeutic merit to intervene the pro-tumorigenic SASP. Similarly, the pharmacological perturbation of the p38-MAPK and MK2 signaling cascade with selective inhibitors 
(e.g., CDD-111, SB203580, UR-13756, and BIRB 796) results in the significant suppression of pro-inflammatory SASP production in replicative senescent cells, which warrants further investigation on inhibiting this axis in age-related pathologies, including cancer $[33,55,151]$.

As noted earlier, the DDR kinases ATM and ATR can impact on the SASP by activating the NF- $k B$ transcription factor via the upstream regulator, GATA4. In agreement with this, the inhibition of the ATM/NF- $\mathrm{KB}$ signaling axis by potent small molecule compounds, KU60019 and KU-55933, suppresses markers of cellular senescence and the SASP, emphasizing the senotherapeutic value of these agents [152-154]. Another level of repression against pro-tumorigenic activities of senescent cancer cells can be achieved by trabectedin, an alkylating agent derived from Ecteinascidia turbinata. Notably, trabectedin modulates the NF- $\mathrm{KB}$ pathway and reduces SASP gene expression in doxorubicin-induced senescent cancer cells resulting in the sensitization to Fas-mediated apoptosis and the inhibition of TIS escape mechanisms [155].

Metformin, an antidiabetic/anti-aging medicine in clinical use for over six decades, also exerts well-established pleiotropic effects towards the inhibition of cancer-promoting signaling pathways [156-158]. Furthermore, metformin is experimentally validated to exert senostatic activity and attenuate the increased burden of senescent cells in many contexts [159-162]. For example, during H-RAS ${ }^{\mathrm{G} 12 \mathrm{~V}}$-induced senescence in human lung fibroblasts, metformin interferes with the activation of the IKK pathway, sparing p38MAPK, and inhibits the nuclear translocation of NF- $\mathrm{KB}$, leading to the suppression of the SASP [162]. In a targeted therapy context, metformin can synergistically enhance the in vitro and in vivo antiproliferative effects of CDK4/6 inhibition in experimental models of head and neck squamous cell carcinoma (HNSCC). In this setting, metformin blocks both the mTOR signaling pathway and the senescence-associated reprogramming of cancer stemness induced by CDK4/ 6 inhibitor, a known Jekyll and Hyde of CDK4/ 6 inhibition in cancer treatment [160]. Thus, metformin can be potentially repositioned as a senostatic agent, alone or in combination with other drugs, in relevant clinical settings for cancer treatment.

Interestingly, many naturally occurring flavonoids including kaempferol, apigenin and wogonin have substantial capacity to effectively suppress cellular senescence and the SASP $[163,164]$. The report by Perrott et al. describes that apigenin downregulates the expression and secretion of several SASP components in senescent human fibroblasts. Although the precise molecular mechanism remains unclear, the findings suggest that apigenin can strongly inhibit the p38-MAPK and NF- $\mathrm{kB}$ pathways. Moreover, the secretome of apigenin-treated senescent fibroblasts, as opposed to untreated controls, fails to induce an aggressive phenotype in breast cancer cells [165]. In accordance with these findings, another study found that wogonin and kaempferol can inhibit NF- $\mathrm{kB}$ activity via IRAK1/I $\mathrm{KB} \alpha$ signaling cascade in DNA damage-induced senescent fibroblasts [166]. Collectively, evidence from these studies merits future investigation of naturally occurring flavones and broad-spectrum anti-inflammatory senostatics to evaluate their translational applicability in cancer cell senescence.

The JAK/STAT pathway plays an important role in chronic sterile inflammation, a hallmark of aging and age-related diseases [167]. Moreover, to a great extent, the accumulation of senescent cells and the SASP contributes to this process [27]. To infer a causal link between the JAK/STAT signaling and the SASP, Xu et al. performed a series of experiments in human primary preadipocytes and human umbilical vein endothelial cells (HUVECs), and aged mice. As anticipated, the inhibition of JAK/STAT pathway by potent JAK1/2-specific inhibitors including JAK inhibitor 1, momelotinib, and ruxolitinib alleviated the SASP in irradiation-induced senescent cells. Further, ruxolitinib decreased both systemic and adipose tissue inflammation and increased physical activity in frail mice [168]. Consistent with these findings, ruxolitinib treatment rescues truncated lamin A (progerin)-induced cellular senescence and the SASP in cultured MRC-5 cells and the Hutchinson-Gilford progeria syndrome (HGPS)-derived fibroblasts. In addition, ruxolitinib administration 
delays premature aging phenotypes in murine model of progeria [169]. Together, the JAK/STAT inhibition can signify a senostatic venue in the context of cancer cell senescence. Simvastatin, an HMG-CoA reductase inhibitor with anti-hyperlipidemic activity, can reduce inflammatory responses by inhibiting the isoprenylation of Rho-family of GTPases [170]. By the same token, simvastatin can suppress the expression of several SASP components in irradiation-induced senescent human fibroblasts, without actually affecting the proliferation arrest and SA- $\beta$-gal activity. More importantly, simvastatin mitigates non-cell-autonomous effects of pro-tumorigenic SASP components by inhibiting paracrine activation of the ERK pathway in breast cancer cells, providing a rationale to explore simvastatin as an anti-SASP agent in cancer therapies [171]. Notably, $\mathrm{Ca}^{2+}$ channel inhibitors, loperamide and nordihydroguaiaretic acid (NDGA), have been recently identified to have senomorphic activity in DNA repair-deficient $E r c c 1^{-1-}$ mouse embryonic fibroblasts [16,172].

Just as importantly, several therapeutic drugs currently available in clinical use for autoimmune and autoinflammatory diseases such as rheumatoid arthritis can directly target the SASP components or their receptors. In this context, the vast majority of the relevant studies focus on targeting IL-1 Receptor (anakinra), IL-6 Receptor (tocilizumab, siltuximab), IL-6 (sirukumab), and TNF- $\alpha$ (adalimumab, etanercept and infliximab) that have an immense potential to be effectively repositioned as precision senostatics to block the detrimental outcomes of the SASP [31,173-176].

In summary, scientific evidence collected through these studies suggest that senostatic agents may potentiate cancer therapies by modulating or inhibiting the proinflammatory SASP components. However, the context-dependent complexity and intensity of the SASP network, and the non-senescence related functions of the SASP factors may be critical limitations to an effective senostatic intervention. Therefore, careful consideration must be given when applying the senostatic agents and future studies will need to focus on addressing these challenges.

\subsection{Senolytic Therapies}

As opposed to normal proliferating cells, senescent cells are highly resilient to cell intrinsic and extrinsic apoptotic stimuli. The Senescent Cell Anti-apoptotic Pathways (SCAPs) are the key molecular players involved in protecting senescent cells from proapoptotic insults, including their own SASP factors [177]. These pro-survival pathways are deemed druggable vulnerabilities and to some extent they represent the Achilles' heel of senescent cells. The SCAPs identified to date include Bcl-2 family of anti-apoptotic proteins (e.g., Bcl-2, Bcl- $\mathrm{X}_{\mathrm{L}}$, Bcl-W, Mcl-1), p53-p21 axis, hypoxia-inducible factor 1-alpha (HIF-1 $\alpha$ ), heat shock protein 90 (Hsp90), several receptor tyrosine kinases, and the PI3K/Akt/mTOR pathway (Figure 3). 


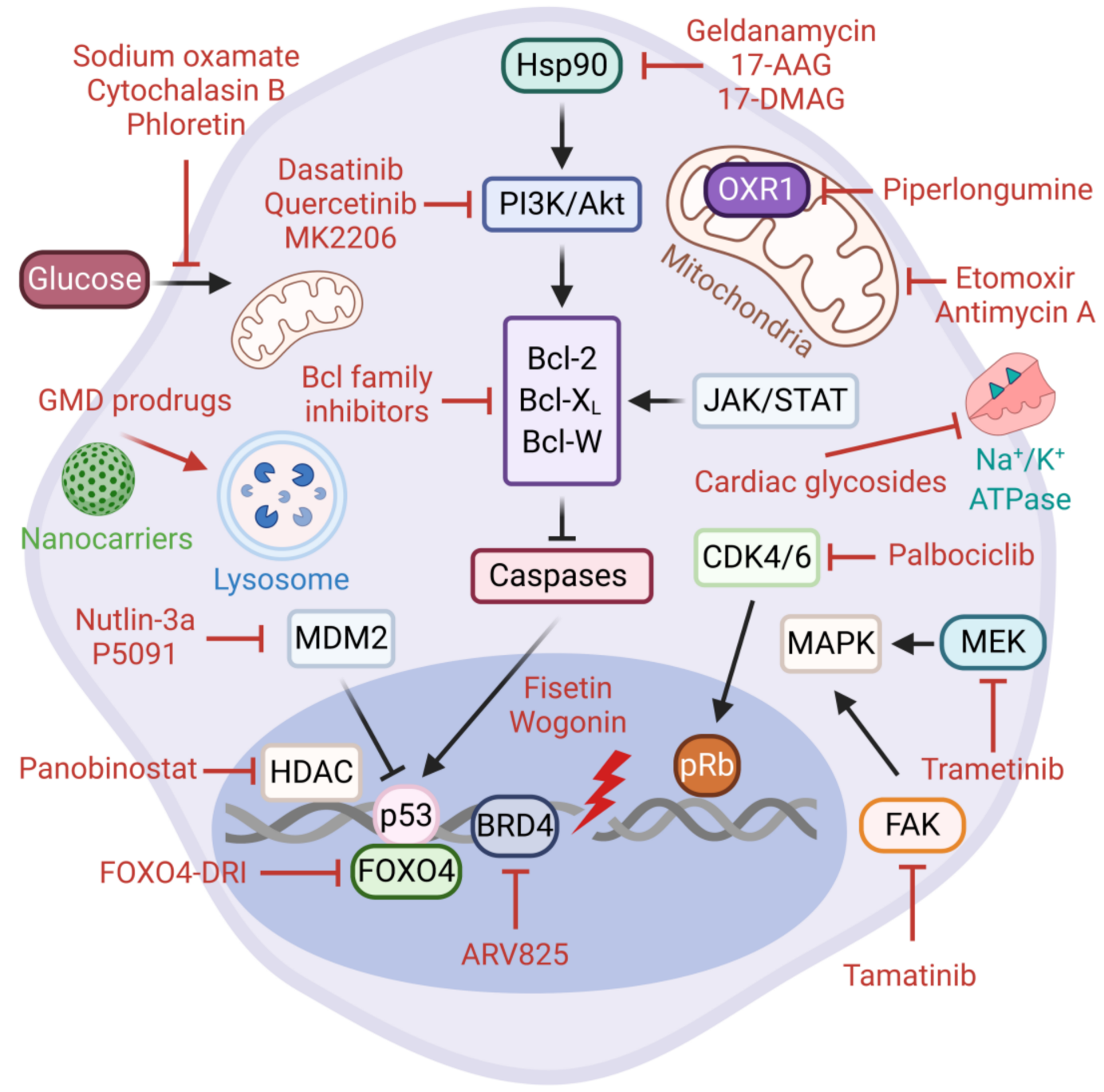

Figure 3. Senolytic therapies. Senolytics mainly target the Senescent Cell Anti-apoptotic Pathways (SCAPs). The SCAPs are activated to protect senescent cells from apoptosis triggered by any form of pro-apoptotic insults, including the SASP. The most common SCAPs are Hsp90, Bcl-2 family proteins, p53, and the PI3K/Akt/mTOR pathway. Several senolytic agents identified to date are depicted. Directed targeting of senescent cells is achieved by the nanoparticle-based delivery of senolytics.

The targeting of SCAPs via senolytic therapies aims to selectively eliminate senescent cells that accumulate in tissues during aging and age-associated pathologies without impacting healthy cells [178-180]. The first senolytic agents were discovered through hypothesis-driven bioinformatics research. These are dasatinib, a dual BCR/ABL and Src family tyrosine kinase inhibitor, and quercetin, a plant flavonoid with potent inhibitory activity against Bcl-2 family members, HIF- $1 \alpha$, and receptor tyrosine kinases including the PI3K/Akt/mTOR signaling pathway. Notably, the senolytic activities of dasatinib and quercetin are cell-type specific, however they display an increased efficacy and range of target cells when used in combination [181-185].

Over the years, new senolytic drugs with a broader spectrum and higher specificity have been discovered. For example, Chang et al. exploited the cell-based phenotypic screening of a chemical compound library and identified a small molecule BH3 mimetic ABT-263 (navitoclax) as an inhibitor of Bcl-2, Bcl-W, and Bcl- $\mathrm{X}_{\mathrm{L}}$ [186]. Navitoclax is a broad-spectrum senolytic which exhibits cell type-independent activity in experimental models of in vivo senescence $[187,188]$. Similarly, ABT-737, an analogue of navitoclax, is senolytic against partial hepatectomy-induced senescent hepatocytes, as well as lung 
and epidermal senescent cells in irradiated mice $[189,190]$. Despite their robust senolytic activity, the existing Bcl-2-targeting inhibitors are unfortunately associated with severe hematological toxicity, prompting the identification of better senolytics with less side effects. Notably, the innovative PROTAC technology is emerging as a powerful strategy to reduce the platelet toxicity of navitoclax [191]. On the same premise, Zhu et al. investigated the senolytic potential of fisetin, yet another example of a natural flavonoid, as well as the two selective Bcl- $\mathrm{X}_{\mathrm{L}}$ inhibitors, A1155463 and A1331852. As expected, these compounds induced apoptosis in senescent HUVECs and human fibroblasts but with less toxicity than navitoclax [192]. Importantly, dietary fisetin can reduce cell viability in several cancer cell lines of breast, colon, lung, HCC, pancreatic, prostate, bladder, and glioma origin [193,194]. Similarly, when co-administered with fisetin, wogonin induces apoptosis in HCC through the activation of the caspase 3 pathway and the accumulation of p53 [195]. Tamatinib (R406), a potent ATP-competitive (Type I) Syk inhibitor, has recently been identified as a novel senolytic in senescent human dermal fibroblasts (HDFs). The senolytic effects of tamatinib were strongly associated with the inhibition of cell survival pathways through the reduced phosphorylation of both focal adhesion kinase (FAK) and p38-MAPK. Interestingly, navitoclax can further potentiate the senolytic activity of tamatinib, suggesting that, alone or in combination with other drugs, tamatinib represents a good candidate for further investigation [196]. In conclusion, the elimination of senescent cells by the inhibition of the central anti-apoptotic factors and their upstream regulatory pathways represents an effective strategy for targeting cancer cell senescence.

Hsp90 is a highly abundant molecular chaperone that plays a critical role in the folding and stabilization of client proteins involved in diverse cellular processes, including cell cycle control, apoptosis, and signal transduction. On this premise, a number of natural or synthetic Hsp90 inhibitors such as geldanamycin and geldanamycin derivatives (17-DMAG and 17-AAG) display senolytic properties in multiple cell types in vitro and animal models in vivo [172,197]. In general, Hsp90 inhibitors pleiotropically target and abrogate NF- $\mathrm{kB}$ and PI3K/Akt/mTOR survival pathways [198]. Consistent with this knowledge, the inactivation of Akt signaling by an allosteric inhibitor, MK2206, can also trigger apoptosis in prostate cancer cells senesced by an androgen antagonist enzalutamide [199]. Piperlongumine, a natural extract with anti-tumor activities in non-small cell lung cancer (NSCLC), is a senolytic in various contexts $[57,113,117,200,201]$. Piperlongumine-induced senolysis is associated with increased ROS production via the degradation of antioxidant protein oxidation resistant 1 (OXR1) and the inhibition of the PI3K/Akt/mTOR pathway [202-204]. Overall, the inhibition of Hsp90 and the client pro-survival pathways can provide robust senolytic activity in certain types of cancer. Panobinostat, an FDA-approved potent inhibitor of histone deacetylase with antineoplastic or cytotoxic activity, can selectively eliminate persistent senescent preneoplastic cells that accumulate following chemotherapytreated NSCLC and HNSCC cell lines [205]. These findings strongly support the evaluation of Panobinostat as a post-chemotherapy senolytic in appropriate clinical settings.

The $\mathrm{p} 53 / \mathrm{p} 21^{\mathrm{Cip} 1}$ axis has also also been evaluated in the context of senolytic interventions. Recent reports have identified Nutlin-3a, a highly specific MDM2 antagonist, and P5091, a ubiquitin specific ligand 7 (USP7) inhibitor, as potent senotherapeutics. These agents promote MDM2 ubiquitination and degradation and the reciprocal accumulation of p53 [206,207]. The forkhead box O (FOXO) transcription factors regulate many cellular processes, including cell cycle progression and apoptosis [208,209]. The interaction between p53 and FOXO4 at the sites of DNA damage contributes to cellular senescence [210]. Recently, a rationally designed D-retro-inverso (DRI) isoform of FOXO4 (FOXO4-DRI) peptide has been shown to block this interaction and promote the nuclear exclusion of p53, which eventually results in the Caspase-3/7-mediated apoptosis of senescent cells. Furthermore, FOXO4-DRI can effectively eliminate doxorubicin-induced senescent cells both in vitro and in vivo and counteract the negative effects of chemotherapy, representing a valuable senolytic opportunity in cancer therapy [211]. 
Increased glucose and lipid metabolism can support survival in senescent cancer cells in the absence of other growth stimuli. Accordingly, the inhibition of glucose metabolism via phloretin, sodium oxamate, or cytochalasin B showed a senolytic effect in therapyinduced senescent lymphomas due to the high dependency of senescent cells on hypermetabolism. From the same perspective, the etomoxir-mediated suppression of fatty acid oxidation as well as the inhibition of oxidative phosphorylation by antimycin A exert a senolytic effect in senescent lymphomas [212]. These results would suggest that hypermetabolism could be potentially exploited as a therapeutic vulnerability in TIS tumors. Furthermore, a novel study by Wakita et al. unveiled the fact that the inhibition of BRD4 activity by BET inhibitor ARV825 is an effective senolytic mechanism through autophagyactivated apoptosis in doxorubicin-induced senescent colorectal cancer cells [213]. This study raises avenues for future investigation-in particular, the potential contribution of autophagy machinery to other senolysis mechanisms.

Another inspiring senolysis approach is based on cardiac glycosides (CGs), which are synthetic or plant-derived steroid-like compounds that selectively inhibit the $\mathrm{Na}^{+} / \mathrm{K}^{+}$. ATPase found on the plasma membrane [214]. CGs are traditionally used to treat atrial fibrillation and cardiac failure [215]. Using a chemical library screening of FDA/EMAapproved drugs and plant extracts, Triana-Martinez et al. identified several CGs, including proscillaridin A, ouabain, and digoxin with strong in vitro senolytic effects on lung cancer and melanoma models, independent of the senescence insult. The same study then tested the senolytic potential of digoxin (a drug in clinical use) on chemotherapy-treated subcutaneous lung tumors and patient-derived xenografts of breast cancer. The combination of digoxin with clinical senogenic anticancer agents eradicated senescent cancer cells and significantly reduced tumor volume and senescent cell markers [216]. Consistent with this, ouabain has been validated to eliminate bystander senescent cells in clinically relevant in vitro and in vivo models of oncogene- and therapy-induced senescence, further contributing to the drug discovery of a broad-spectrum senolytic arsenal [217].

In conclusion, senescent cancer cells can evade apoptosis through the activation of antiapoptotic and pro-survival mechanisms (collectively, the SCAP network), which potentially enables them to resist self-destruction. Therefore, the inhibition of SCAP-related molecules individually or the combinatorial targeting of multiple components across the SCAP network can result in selective apoptosis, highlighting the clinical utility of these strategies. Although many of the currently available senolytic drugs have certain drawbacks, those with strong preclinical data and limited off-target toxicities, in particular, are likely to translate into clinical research in the near future.

\subsection{Directed Targeting of Senescent Cells}

Although senotherapies are decisively formulated to execute selective cytotoxic action in senescent cells, there are often side effects inherent to the course of delivery and implementation. In recent years, novel tools and versatile systems have been developed to directly deliver and release therapeutic compounds into senescent cells. One of these modern-day biomedicine tools is based on the encapsulation of senolytic drugs by galacto-oligosaccharide-coated silica porous scaffold nanoparticles (GalNP). Functionalized GalNP carriers can successfully transport and deliver small molecules such as doxorubicin and navitoclax to CDK4/6 inhibitor palbociclib-induced senescent lesions in vivo. Upon endocytosis and fusion with lysosomal vehicles, the cargoes are efficiently released by $\beta$-galactosidase-mediated hydrolysis, promoting GalNP-mediated senolysis and the subsequent regression of melanoma and lung squamous cell carcinoma tumor xenografts. Finally, using GalNPs for delivery effectively reduces the common cytotoxic effects of doxorubicin and navitoclax [218]. In essence, the synergistic treatment of senescence inducers and senolytic compounds is seemingly conceivable with such nanoparticle tools [219]. Additional proof-of-concept drug delivery studies confirm that nanocarriers entail a remarkable potential for senotherapies which can be further improved by changing their size and composition or tethering them to different polymers and epitopes (e.g., $\beta 2$ 
microglobulin) or antibodies (e.g., CD9) against membrane markers in order to provide enhanced selectivity against senescent lesions [220-224].

Increased lysosomal content accompanied by elevated levels of SA- $\beta$-gal activity is a universal marker of senescent cells. Within this framework, several groups have recently opted to develop a new class of broad spectrum senolytic agents using this marker. In one of these strategies, galactose-modified duocarmycin (GMD) prodrugs are favorably processed in senescent cells by lysosomal $\beta$-galactosidase. Duocarmycin is a non-specific cytotoxic DNA-alkylating compound, however the enzymatic conversion of GMDs into duocarmycin drugs causes the specific destruction of senescent cells in vitro and in vivo, without affecting normal cells when applied at low doses. The study has also shown that GMD prodrugs can effectively eliminate chemotherapy-associated bystander senescent cells in preneoplastic lesions [225]. Gemcitabine-derivative SSK1 is another recently developed lysosomal SA- $\beta$-gal-responsive prodrug that selectively kills senescent cells in vitro and in vivo, independent of the senescence inducer [226].

\section{Conclusions}

Overall, cancer cell senescence is a Jekyll and Hyde phenomenon with both beneficial and detrimental implications. Despite a primary and immediate tumor-suppressive role against cancer development, the long-term consequences of senescent cancer cells are potentially deleterious. Recent advances in senotherapeutic strategies targeting senescent cells and their SASP has expanded the field of translational research on cancer therapies. The series of basic and translational studies presented in this review is exceptionally promising yet somewhat challenging to implement. This is partly because the pathways being targeted by existing senotherapies function in non-senescent cells, and their high dose and long-term use may cause adverse effects on other cell-types and tissues. Thus, safety issues pose a major concern, especially when the drugs are administered systemically. There are several possible ways to obtain higher efficacy and better safety profiles, such as focusing on the spatiotemporal optimization of treatments and using less toxic doses of senotherapeutic drugs by developing combination therapies and senescent cell-specific delivery systems. Another limitation with the current studies is that the experimental models may not perfectly recapitulate the heterogeneous and complex nature of disease conditions specific to human pathophysiology. Nonetheless, we envision that a comprehensive understanding of the cellular senescence mechanisms and careful evaluation of the heterogeneous nature of senescent cancer cell populations will help better translate these findings into clinical settings.

Author Contributions: B.D., D.D., and F.A.M. contributed to the conceptual proposal, performed the literature search and review, and contributed to the writing and editing of the manuscript. B.D. and D.D. prepared the figures. S.S. conceptualized the proposal, contributed to the literature search and review, provided guidance, and wrote and edited the manuscript. B.D. and D.D. contributed equally to this work. All authors have read and agreed to the published version of the manuscript.

Funding: This research was funded by the Scientific and Technological Research Council of Turkey (TUBITAK) via project number 217Z168.

Acknowledgments: Serif Senturk is a recipient of the Young Scientists Award Program of the Turkish Academy of Sciences (TUBA GEBIP 2017) and the Science Academy's Young Scientist Awards Program (BAGEP 2019). We thank Ece Cakiroglu for the critical reading of the manuscript. The figures were created with BioRender.com.

Conflicts of Interest: The authors declare no conflict of interest.

\section{References}

1. Hayflick, L.; Moorhead, P.S. The Serial Cultivation of Human Diploid Cell Strains. Exp. Cell Res. 1961, 25, 585-621. [CrossRef]

2. Hayflick, L. The Limited in Vitro Lifetime of Human Diploid Cell Strains. Exp. Cell Res. 1965, 37, 614-636. [CrossRef]

3. Campisi, J. Replicative Senescence: An Old Lives' Tale? Cell 1996, 84, 497-500. [CrossRef]

4. Shay, J.W.; Wright, W.E. Hayflick, His Limit, and Cellular Ageing. Nat. Rev. Mol. Cell Biol. 2000, 1, 72-76. [CrossRef] 
5. $\quad$ di Fagagna, F.D.; Reaper, P.M.; Clay-Farrace, L.; Fiegler, H.; Carr, P.; von Zglinicki, T.; Saretzki, G.; Carter, N.P.; Jackson, S.P. A DNA Damage Checkpoint Response in Telomere-Initiated Senescence. Nature 2003, 426, 194-198. [CrossRef]

6. Goldstein, S. Replicative Senescence: The Human Fibroblast Comes of Age. Science 1990, 249, 1129-1133. [CrossRef]

7. Galluzzi, L.; Yamazaki, T.; Kroemer, G. Linking Cellular Stress Responses to Systemic Homeostasis. Nat. Rev. Mol. Cell Biol. 2018, 19, 731-745. [CrossRef]

8. Campisi, J.; d'Adda di Fagagna, F. Cellular Senescence: When Bad Things Happen to Good Cells. Nat. Rev. Mol. Cell Biol. 2007, 8, 729-740. [CrossRef]

9. Van Deursen, J.M. The Role of Senescent Cells in Ageing. Nature 2014, 509, 439-446. [CrossRef]

10. McHugh, D.; Gil, J. Senescence and Aging: Causes, Consequences, and Therapeutic Avenues. J. Cell Biol. 2018, 217, 65-77. [CrossRef]

11. Childs, B.G.; Durik, M.; Baker, D.J.; van Deursen, J.M. Cellular Senescence in Aging and Age-Related Disease: From Mechanisms to Therapy. Nat. Med. 2015, 21, 1424-1435. [CrossRef] [PubMed]

12. Muñoz-Espín, D.; Serrano, M. Cellular Senescence: From Physiology to Pathology. Nat. Rev. Mol. Cell Biol. 2014, 15, 482-496. [CrossRef] [PubMed]

13. Kuilman, T.; Michaloglou, C.; Mooi, W.J.; Peeper, D.S. The Essence of Senescence. Genes Dev. 2010, 24, 2463-2479. [CrossRef] [PubMed]

14. Narita, M.; Lowe, S.W. Senescence Comes of Age. Nat. Med. 2005, 11, 920-922. [CrossRef] [PubMed]

15. Campisi, J. Cellular Senescence as a Tumor-Suppressor Mechanism. Trends Cell Biol. 2001, 11, S27-S31. [CrossRef]

16. Lozano-Torres, B.; Estepa-Fernández, A.; Rovira, M.; Orzáez, M.; Serrano, M.; Martínez-Máñez, R.; Sancenón, F. The Chemistry of Senescence. Nat. Rev. Chem. 2019, 3, 426-441. [CrossRef]

17. Beauséjour, C.M.; Krtolica, A.; Galimi, F.; Narita, M.; Lowe, S.W.; Yaswen, P.; Campisi, J. Reversal of Human Cellular Senescence: Roles of the P53 and P16 Pathways. EMBO J. 2003, 22, 4212-4222. [CrossRef]

18. Hoare, M.; Narita, M. Transmitting Senescence to the Cell Neighbourhood. Nat. Cell Biol. 2013, 15, 887-889. [CrossRef]

19. Mavrogonatou, E.; Pratsinis, H.; Kletsas, D. The Role of Senescence in Cancer Development. Semin. Cancer Biol. 2020, 62, $182-191$. [CrossRef]

20. Dimri, G.P.; Lee, X.; Basile, G.; Acosta, M.; Scott, G.; Roskelley, C.; Medrano, E.E.; Linskens, M.; Rubelj, I.; Pereira-Smith, O. A Biomarker That Identifies Senescent Human Cells in Culture and in Aging Skin in Vivo. Proc. Natl. Acad. Sci. USA 1995, 92, 9363-9367. [CrossRef]

21. Hernandez-Segura, A.; Nehme, J.; Demaria, M. Hallmarks of Cellular Senescence. Trends Cell Biol. 2018, 28, 436-453. [CrossRef] [PubMed]

22. Zhang, R.; Chen, W.; Adams, P.D. Molecular Dissection of Formation of Senescence-Associated Heterochromatin Foci. Mol. Cell. Biol. 2007, 27, 2343-2358. [CrossRef] [PubMed]

23. Sen, P.; Shah, P.P.; Nativio, R.; Berger, S.L. Epigenetic Mechanisms of Longevity and Aging. Cell 2016, 166, 822-839. [CrossRef] [PubMed]

24. Victorelli, S.; Passos, J.F. Telomeres and Cell Senescence-Size Matters Not. EBioMedicine 2017, 21, 14-20. [CrossRef]

25. Kuilman, T.; Peeper, D.S. Senescence-Messaging Secretome: SMS-Ing Cellular Stress. Nat. Rev. Cancer 2009, 9, 81-94. [CrossRef]

26. Acosta, J.C.; Banito, A.; Wuestefeld, T.; Georgilis, A.; Janich, P.; Morton, J.P.; Athineos, D.; Kang, T.-W.; Lasitschka, F.; Andrulis, M.; et al. A Complex Secretory Program Orchestrated by the Inflammasome Controls Paracrine Senescence. Nat. Cell Biol. 2013, 15, 978-990. [CrossRef]

27. Tchkonia, T.; Zhu, Y.; van Deursen, J.; Campisi, J.; Kirkland, J.L. Cellular Senescence and the Senescent Secretory Phenotype: Therapeutic Opportunities. J. Clin. Invest. 2013, 123, 966-972. [CrossRef]

28. Wallis, R.; Mizen, H.; Bishop, C.L. The Bright and Dark Side of Extracellular Vesicles in the Senescence-Associated Secretory Phenotype. Mech. Ageing Dev. 2020, 189, 111263. [CrossRef]

29. Terlecki-Zaniewicz, L.; Lämmermann, I.; Latreille, J.; Bobbili, M.R.; Pils, V.; Schosserer, M.; Weinmüllner, R.; Dellago, H.; Skalicky, S.; Pum, D.; et al. Small Extracellular Vesicles and Their MiRNA Cargo Are Anti-Apoptotic Members of the Senescence-Associated Secretory Phenotype. Aging 2018, 10, 1103-1132. [CrossRef]

30. Basisty, N.; Kale, A.; Jeon, O.H.; Kuehnemann, C.; Payne, T.; Rao, C.; Holtz, A.; Shah, S.; Sharma, V.; Ferrucci, L.; et al. A Proteomic Atlas of Senescence-Associated Secretomes for Aging Biomarker Development. PLOS Biol. 2020, 18, e3000599. [CrossRef]

31. Faget, D.V.; Ren, Q.; Stewart, S.A. Unmasking Senescence: Context-Dependent Effects of SASP in Cancer. Nat. Rev. Cancer 2019, 19, 439-453. [CrossRef] [PubMed]

32. Freund, A.; Patil, C.K.; Campisi, J. P38MAPK Is a Novel DNA Damage Response-Independent Regulator of the SenescenceAssociated Secretory Phenotype. EMBO J. 2011, 30, 1536-1548. [CrossRef] [PubMed]

33. Birch, J.; Gil, J. Senescence and the SASP: Many Therapeutic Avenues. Genes Dev. 2020, 34, 1565-1576. [CrossRef]

34. Lopes-Paciencia, S.; Saint-Germain, E.; Rowell, M.-C.; Ruiz, A.F.; Kalegari, P.; Ferbeyre, G. The Senescence-Associated Secretory Phenotype and Its Regulation. Cytokine 2019, 117, 15-22. [CrossRef] [PubMed]

35. Glück, S.; Guey, B.; Gulen, M.F.; Wolter, K.; Kang, T.-W.; Schmacke, N.A.; Bridgeman, A.; Rehwinkel, J.; Zender, L.; Ablasser, A. Innate Immune Sensing of Cytosolic Chromatin Fragments through CGAS Promotes Senescence. Nat. Cell Biol. 2017, 19, 1061-1070. [CrossRef] 
36. Dou, Z.; Ghosh, K.; Vizioli, M.G.; Zhu, J.; Sen, P.; Wangensteen, K.J.; Simithy, J.; Lan, Y.; Lin, Y.; Zhou, Z.; et al. Cytoplasmic Chromatin Triggers Inflammation in Senescence and Cancer. Nature 2017, 550, 402-406. [CrossRef]

37. Chien, Y.; Scuoppo, C.; Wang, X.; Fang, X.; Balgley, B.; Bolden, J.E.; Premsrirut, P.; Luo, W.; Chicas, A.; Lee, C.S.; et al. Control of the Senescence-Associated Secretory Phenotype by NF-KB Promotes Senescence and Enhances Chemosensitivity. Genes Dev. 2011, 25, 2125-2136. [CrossRef]

38. Salotti, J.; Johnson, P.F. Regulation of Senescence and the SASP by the Transcription Factor C/EBP $\beta$. Exp. Gerontol. 2019, 128, 110752. [CrossRef]

39. Acosta, J.C.; O’Loghlen, A.; Banito, A.; Guijarro, M.V.; Augert, A.; Raguz, S.; Fumagalli, M.; Da Costa, M.; Brown, C.; Popov, N.; et al. Chemokine Signaling via the CXCR2 Receptor Reinforces Senescence. Cell 2008, 133, 1006-1018. [CrossRef]

40. Lee, S.; Schmitt, C.A. The Dynamic Nature of Senescence in Cancer. Nat. Cell Biol. 2019, 21, 94-101. [CrossRef]

41. Hoare, M.; Ito, Y.; Kang, T.-W.; Weekes, M.P.; Matheson, N.J.; Patten, D.A.; Shetty, S.; Parry, A.J.; Menon, S.; Salama, R.; et al. NOTCH1 Mediates a Switch between Two Distinct Secretomes during Senescence. Nat. Cell Biol. 2016, 18, 979-992. [CrossRef] [PubMed]

42. Rodier, F.; Coppé, J.-P.; Patil, C.K.; Hoeijmakers, W.A.M.; Muñoz, D.P.; Raza, S.R.; Freund, A.; Campeau, E.; Davalos, A.R.; Campisi, J. Persistent DNA Damage Signalling Triggers Senescence-Associated Inflammatory Cytokine Secretion. Nat. Cell Biol. 2009, 11, 973-979. [CrossRef] [PubMed]

43. Kang, C.; Xu, Q.; Martin, T.D.; Li, M.Z.; Demaria, M.; Aron, L.; Lu, T.; Yankner, B.A.; Campisi, J.; Elledge, S.J. The DNA Damage Response Induces Inflammation and Senescence by Inhibiting Autophagy of GATA4. Science 2015, 349, aaa5612. [CrossRef] [PubMed]

44. Kaplon, J.; Zheng, L.; Meissl, K.; Chaneton, B.; Selivanov, V.A.; Mackay, G.; van der Burg, S.H.; Verdegaal, E.M.E.; Cascante, M.; Shlomi, T.; et al. A Key Role for Mitochondrial Gatekeeper Pyruvate Dehydrogenase in Oncogene-Induced Senescence. Nature 2013, 498, 109-112. [CrossRef] [PubMed]

45. Muñoz-Espín, D.; Cañamero, M.; Maraver, A.; Gómez-López, G.; Contreras, J.; Murillo-Cuesta, S.; Rodríguez-Baeza, A.; VarelaNieto, I.; Ruberte, J.; Collado, M.; et al. Programmed Cell Senescence during Mammalian Embryonic Development. Cell 2013, 155, 1104-1118. [CrossRef] [PubMed]

46. Ito, T.; Teo, Y.V.; Evans, S.A.; Neretti, N.; Sedivy, J.M. Regulation of Cellular Senescence by Polycomb Chromatin Modifiers through Distinct DNA Damage- and Histone Methylation-Dependent Pathways. Cell Rep. 2018, 22, 3480-3492. [CrossRef]

47. Wiley, C.D.; Velarde, M.C.; Lecot, P.; Liu, S.; Sarnoski, E.A.; Freund, A.; Shirakawa, K.; Lim, H.W.; Davis, S.S.; Ramanathan, A.; et al. Mitochondrial Dysfunction Induces Senescence with a Distinct Secretory Phenotype. Cell Metab. 2016, 23 , 303-314. [CrossRef]

48. Chen, H.; Ruiz, P.D.; McKimpson, W.M.; Novikov, L.; Kitsis, R.N.; Gamble, M.J. MacroH2A1 and ATM Play Opposing Roles in Paracrine Senescence and the Senescence-Associated Secretory Phenotype. Mol. Cell 2015, 59, 719-731. [CrossRef]

49. Contrepois, K.; Coudereau, C.; Benayoun, B.A.; Schuler, N.; Roux, P.-F.; Bischof, O.; Courbeyrette, R.; Carvalho, C.; Thuret, J.-Y.; Ma, Z.; et al. Histone Variant H2A.J Accumulates in Senescent Cells and Promotes Inflammatory Gene Expression. Nat. Commun. 2017, 8, 14995. [CrossRef]

50. Davalos, A.R.; Kawahara, M.; Malhotra, G.K.; Schaum, N.; Huang, J.; Ved, U.; Beausejour, C.M.; Coppe, J.-P.; Rodier, F.; Campisi, J. P53-Dependent Release of Alarmin HMGB1 Is a Central Mediator of Senescent Phenotypes. J. Cell Biol. 2013, 201, 613-629. [CrossRef]

51. Pazolli, E.; Alspach, E.; Milczarek, A.; Prior, J.; Piwnica-Worms, D.; Stewart, S.A. Chromatin Remodeling Underlies the SenescenceAssociated Secretory Phenotype of Tumor Stromal Fibroblasts That Supports Cancer Progression. Cancer Res. 2012, 72, $2251-2261$. [CrossRef] [PubMed]

52. Tasdemir, N.; Banito, A.; Roe, J.-S.; Alonso-Curbelo, D.; Camiolo, M.; Tschaharganeh, D.F.; Huang, C.-H.; Aksoy, O.; Bolden, J.E.; Chen, C.-C.; et al. BRD4 Connects Enhancer Remodeling to Senescence Immune Surveillance. Cancer Discov. 2016, 6, 612-629. [CrossRef] [PubMed]

53. Capell, B.C.; Drake, A.M.; Zhu, J.; Shah, P.P.; Dou, Z.; Dorsey, J.; Simola, D.F.; Donahue, G.; Sammons, M.; Rai, T.S.; et al. MLL1 Is Essential for the Senescence-Associated Secretory Phenotype. Genes Dev. 2016, 30, 321-336. [CrossRef] [PubMed]

54. Hayakawa, T.; Iwai, M.; Aoki, S.; Takimoto, K.; Maruyama, M.; Maruyama, W.; Motoyama, N. SIRT1 Suppresses the SenescenceAssociated Secretory Phenotype through Epigenetic Gene Regulation. PLoS ONE 2015, 10, e0116480. [CrossRef]

55. Alspach, E.; Flanagan, K.C.; Luo, X.; Ruhland, M.K.; Huang, H.; Pazolli, E.; Donlin, M.J.; Marsh, T.; Piwnica-Worms, D.; Monahan, J.; et al. P38MAPK Plays a Crucial Role in Stromal-Mediated Tumorigenesis. Cancer Discov. 2014, 4, 716-729. [CrossRef]

56. Herranz, N.; Gallage, S.; Mellone, M.; Wuestefeld, T.; Klotz, S.; Hanley, C.J.; Raguz, S.; Acosta, J.C.; Innes, A.J.; Banito, A.; et al. MTOR Regulates MAPKAPK2 Translation to Control the Senescence-Associated Secretory Phenotype. Nat. Cell Biol. 2015, 17, 1205-1217. [CrossRef]

57. Paez-Ribes, M.; González-Gualda, E.; Doherty, G.J.; Muñoz-Espín, D. Targeting Senescent Cells in Translational Medicine. EMBO Mol. Med. 2019, 11, e10234. [CrossRef]

58. Herranz, N.; Gil, J. Mechanisms and Functions of Cellular Senescence. J. Clin. Invest. 2018, 128, 1238-1246. [CrossRef]

59. Sherr, C.J.; McCormick, F. The RB and P53 Pathways in Cancer. Cancer Cell 2002, 2, 103-112. [CrossRef]

60. Gorgoulis, V.; Adams, P.D.; Alimonti, A.; Bennett, D.C.; Bischof, O.; Bishop, C.; Campisi, J.; Collado, M.; Evangelou, K.; Ferbeyre, G.; et al. Cellular Senescence: Defining a Path Forward. Cell 2019, 179, 813-827. [CrossRef] 
61. Narita, M.; Nũnez, S.; Heard, E.; Narita, M.; Lin, A.W.; Hearn, S.A.; Spector, D.L.; Hannon, G.J.; Lowe, S.W. Rb-Mediated Heterochromatin Formation and Silencing of E2F Target Genes during Cellular Senescence. Cell 2003, 113, 703-716. [CrossRef]

62. Chicas, A.; Wang, X.; Zhang, C.; McCurrach, M.; Zhao, Z.; Mert, O.; Dickins, R.A.; Narita, M.; Zhang, M.; Lowe, S.W. Dissecting the Unique Role of the Retinoblastoma Tumor Suppressor during Cellular Senescence. Cancer Cell 2010, 17, 376-387. [CrossRef] [PubMed]

63. Hara, E.; Smith, R.; Parry, D.; Tahara, H.; Stone, S.; Peters, G. Regulation of P16CDKN2 Expression and Its Implications for Cell Immortalization and Senescence. Mol. Cell. Biol. 1996, 16, 859-867. [CrossRef] [PubMed]

64. Chen, Z.; Trotman, L.C.; Shaffer, D.; Lin, H.-K.; Dotan, Z.A.; Niki, M.; Koutcher, J.A.; Scher, H.I.; Ludwig, T.; Gerald, W.; et al. Crucial Role of P53-Dependent Cellular Senescence in Suppression of Pten-Deficient Tumorigenesis. Nature 2005, 436, 725-730. [CrossRef]

65. Itahana, K.; Dimri, G.; Campisi, J. Regulation of Cellular Senescence by P53: P53 and Cellular Senescence. Eur. J. Biochem. 2001, 268, 2784-2791. [CrossRef]

66. Rufini, A.; Tucci, P.; Celardo, I.; Melino, G. Senescence and Aging: The Critical Roles of P53. Oncogene 2013, 32, 5129-5143. [CrossRef]

67. Chan, S.R.W.L.; Blackburn, E.H. Telomeres and Telomerase. Philos. Trans. R. Soc. Lond. B. Biol. Sci. 2004, 359, 109-121. [CrossRef]

68. McClintock, B. The Stability of Broken Ends of Chromosomes in Zea Mays. Genetics 1941, 26, $234-282$.

69. Olovnikov, A.M. A Theory of Marginotomy. The Incomplete Copying of Template Margin in Enzymic Synthesis of Polynucleotides and Biological Significance of the Phenomenon. J. Theor. Biol. 1973, 41, 181-190. [CrossRef]

70. Watson, J.D. Origin of Concatemeric T7 DNA. Nat. New Biol. 1972, 239, 197-201. [CrossRef]

71. Blackburn, E.H. Switching and Signaling at the Telomere. Cell 2001, 106, 661-673. [CrossRef]

72. Wright, W.E.; Piatyszek, M.A.; Rainey, W.E.; Byrd, W.; Shay, J.W. Telomerase Activity in Human Germline and Embryonic Tissues and Cells. Dev. Genet. 1996, 18, 173-179. [CrossRef]

73. Counter, C.M.; Avilion, A.A.; LeFeuvre, C.E.; Stewart, N.G.; Greider, C.W.; Harley, C.B.; Bacchetti, S. Telomere Shortening Associated with Chromosome Instability Is Arrested in Immortal Cells Which Express Telomerase Activity. EMBO J. 1992, 11, 1921-1929. [CrossRef] [PubMed]

74. Harley, C.B.; Futcher, A.B.; Greider, C.W. Telomeres Shorten during Ageing of Human Fibroblasts. Nature 1990, 345, 458-460. [CrossRef] [PubMed]

75. Kim, N.W.; Piatyszek, M.A.; Prowse, K.R.; Harley, C.B.; West, M.D.; Ho, P.L.; Coviello, G.M.; Wright, W.E.; Weinrich, S.L.; Shay, J.W. Specific Association of Human Telomerase Activity with Immortal Cells and Cancer. Science 1994, 266, 2011-2015. [CrossRef]

76. Bodnar, A.G.; Ouellette, M.; Frolkis, M.; Holt, S.E.; Chiu, C.P.; Morin, G.B.; Harley, C.B.; Shay, J.W.; Lichtsteiner, S.; Wright, W.E. Extension of Life-Span by Introduction of Telomerase into Normal Human Cells. Science 1998, 279, 349-352. [CrossRef]

77. Vaziri, H.; Benchimol, S. Reconstitution of Telomerase Activity in Normal Human Cells Leads to Elongation of Telomeres and Extended Replicative Life Span. Curr. Biol. CB 1998, 8, 279-282. [CrossRef]

78. Hanahan, D.; Weinberg, R.A. Hallmarks of Cancer: The next Generation. Cell 2011, 144, 646-674. [CrossRef]

79. Huang, F.W.; Hodis, E.; Xu, M.J.; Kryukov, G.V.; Chin, L.; Garraway, L.A. Highly Recurrent TERT Promoter Mutations in Human Melanoma. Science 2013, 339, 957-959. [CrossRef]

80. Horn, S.; Figl, A.; Rachakonda, P.S.; Fischer, C.; Sucker, A.; Gast, A.; Kadel, S.; Moll, I.; Nagore, E.; Hemminki, K.; et al. TERT Promoter Mutations in Familial and Sporadic Melanoma. Science 2013, 339, 959-961. [CrossRef]

81. Borah, S.; Xi, L.; Zaug, A.J.; Powell, N.M.; Dancik, G.M.; Cohen, S.B.; Costello, J.C.; Theodorescu, D.; Cech, T.R. Cancer. TERT Promoter Mutations and Telomerase Reactivation in Urothelial Cancer. Science 2015, 347, 1006-1010. [CrossRef] [PubMed]

82. Shay, J.W.; Wright, W.E. Role of Telomeres and Telomerase in Cancer. Semin. Cancer Biol. 2011, 21, 349-353. [CrossRef] [PubMed]

83. Yuan, X.; Larsson, C.; Xu, D. Mechanisms Underlying the Activation of TERT Transcription and Telomerase Activity in Human Cancer: Old Actors and New Players. Oncogene 2019, 38, 6172-6183. [CrossRef]

84. Senturk, S.; Mumcuoglu, M.; Gursoy-Yuzugullu, O.; Cingoz, B.; Akcali, K.C.; Ozturk, M. Transforming Growth Factor-Beta Induces Senescence in Hepatocellular Carcinoma Cells and Inhibits Tumor Growth. Hepatol. Baltim. Md 2010, 52, 966-974. [CrossRef]

85. Serrano, M.; Lin, A.W.; McCurrach, M.E.; Beach, D.; Lowe, S.W. Oncogenic Ras Provokes Premature Cell Senescence Associated with Accumulation of P53 and P16INK4a. Cell 1997, 88, 593-602. [CrossRef]

86. Davalli, P.; Mitic, T.; Caporali, A.; Lauriola, A.; D'Arca, D. ROS, Cell Senescence, and Novel Molecular Mechanisms in Aging and Age-Related Diseases. Oxid. Med. Cell. Longev. 2016, 2016, 3565127. [CrossRef]

87. Di Micco, R.; Fumagalli, M.; Cicalese, A.; Piccinin, S.; Gasparini, P.; Luise, C.; Schurra, C.; Garre', M.; Nuciforo, P.G.; Bensimon, A.; et al. Oncogene-Induced Senescence Is a DNA Damage Response Triggered by DNA Hyper-Replication. Nature 2006, 444, 638-642. [CrossRef]

88. Vasileiou, P.V.S.; Evangelou, K.; Vlasis, K.; Fildisis, G.; Panayiotidis, M.I.; Chronopoulos, E.; Passias, P.-G.; Kouloukoussa, M.; Gorgoulis, V.G.; Havaki, S. Mitochondrial Homeostasis and Cellular Senescence. Cells 2019, 8, 686. [CrossRef]

89. Pluquet, O.; Pourtier, A.; Abbadie, C. The Unfolded Protein Response and Cellular Senescence. A Review in the Theme: Cellular Mechanisms of Endoplasmic Reticulum Stress Signaling in Health and Disease. Am. J. Physiol. Cell Physiol. 2015, 308, C415-C425. [CrossRef] 
90. Fernandez-Rebollo, E.; Franzen, J.; Goetzke, R.; Hollmann, J.; Ostrowska, A.; Oliverio, M.; Sieben, T.; Rath, B.; Kornfeld, J.-W.; Wagner, W. Senescence-Associated Metabolomic Phenotype in Primary and IPSC-Derived Mesenchymal Stromal Cells. Stem Cell Rep. 2020, 14, 201-209. [CrossRef]

91. Wyld, L.; Bellantuono, I.; Tchkonia, T.; Morgan, J.; Turner, O.; Foss, F.; George, J.; Danson, S.; Kirkland, J.L. Senescence and Cancer: A Review of Clinical Implications of Senescence and Senotherapies. Cancers 2020, 12, 2134. [CrossRef] [PubMed]

92. Davaapil, H.; Brockes, J.P.; Yun, M.H. Conserved and Novel Functions of Programmed Cellular Senescence during Vertebrate Development. Dev. Camb. Engl. 2017, 144, 106-114. [CrossRef] [PubMed]

93. Salama, R.; Sadaie, M.; Hoare, M.; Narita, M. Cellular Senescence and Its Effector Programs. Genes Dev. 2014, $28,99-114$. [CrossRef] [PubMed]

94. Burton, D.G.A.; Stolzing, A. Cellular Senescence: Immunosurveillance and Future Immunotherapy. Ageing Res. Rev. 2018, 43, 17-25. [CrossRef]

95. Finkel, T.; Serrano, M.; Blasco, M.A. The Common Biology of Cancer and Ageing. Nature 2007, 448, 767-774. [CrossRef]

96. Coppé, J.-P.; Desprez, P.-Y.; Krtolica, A.; Campisi, J. The Senescence-Associated Secretory Phenotype: The Dark Side of Tumor Suppression. Annu. Rev. Pathol. 2010, 5, 99-118. [CrossRef]

97. Sturmlechner, I.; Durik, M.; Sieben, C.J.; Baker, D.J.; van Deursen, J.M. Cellular Senescence in Renal Ageing and Disease. Nat. Rev. Nephrol. 2017, 13, 77-89. [CrossRef]

98. Lunyak, V.V.; Amaro-Ortiz, A.; Gaur, M. Mesenchymal Stem Cells Secretory Responses: Senescence Messaging Secretome and Immunomodulation Perspective. Front. Genet. 2017, 8, 220. [CrossRef]

99. Schmitt, C.A.; Lowe, S.W. Apoptosis and Therapy. J. Pathol. 1999, 187, 127-137. [CrossRef]

100. Hannun, Y.A. Apoptosis and the Dilemma of Cancer Chemotherapy. Blood 1997, 89, 1845-1853. [CrossRef]

101. Pommier, Y.; Sordet, O.; Antony, S.; Hayward, R.L.; Kohn, K.W. Apoptosis Defects and Chemotherapy Resistance: Molecular Interaction Maps and Networks. Oncogene 2004, 23, 2934-2949. [CrossRef] [PubMed]

102. Longley, D.B.; Johnston, P.G. Molecular Mechanisms of Drug Resistance. J. Pathol. 2005, 205, 275-292. [CrossRef] [PubMed]

103. Housman, G.; Byler, S.; Heerboth, S.; Lapinska, K.; Longacre, M.; Snyder, N.; Sarkar, S. Drug Resistance in Cancer: An Overview. Cancers 2014, 6, 1769-1792. [CrossRef]

104. Millar, A.W.; Lynch, K.P. Rethinking Clinical Trials for Cytostatic Drugs. Nat. Rev. Cancer 2003, 3, 540-545. [CrossRef] [PubMed]

105. Nardella, C.; Clohessy, J.G.; Alimonti, A.; Pandolfi, P.P. Pro-Senescence Therapy for Cancer Treatment. Nat. Rev. Cancer 2011, 11, 503-511. [CrossRef]

106. Lee, M.; Lee, J.-S. Exploiting Tumor Cell Senescence in Anticancer Therapy. BMB Rep. 2014, 47, 51-59. [CrossRef]

107. Ewald, J.A.; Desotelle, J.A.; Wilding, G.; Jarrard, D.F. Therapy-Induced Senescence in Cancer. J. Natl. Cancer Inst. 2010, 102, 1536-1546. [CrossRef]

108. Wang, X.; Wong, S.C.; Pan, J.; Tsao, S.W.; Fung, K.H.; Kwong, D.L.; Sham, J.S.; Nicholls, J.M. Evidence of Cisplatin-Induced Senescent-like Growth Arrest in Nasopharyngeal Carcinoma Cells. Cancer Res. 1998, 58, 5019-5022.

109. Elmore, L.W.; Rehder, C.W.; Di, X.; McChesney, P.A.; Jackson-Cook, C.K.; Gewirtz, D.A.; Holt, S.E. Adriamycin-Induced Senescence in Breast Tumor Cells Involves Functional P53 and Telomere Dysfunction. J. Biol. Chem. 2002, 277, 35509-35515. [CrossRef]

110. te Poele, R.H.; Okorokov, A.L.; Jardine, L.; Cummings, J.; Joel, S.P. DNA Damage Is Able to Induce Senescence in Tumor Cells in Vitro and in Vivo. Cancer Res. 2002, 62, 1876-1883.

111. Gewirtz, D.A.; Holt, S.E.; Elmore, L.W. Accelerated Senescence: An Emerging Role in Tumor Cell Response to Chemotherapy and Radiation. Biochem. Pharmacol. 2008, 76, 947-957. [CrossRef] [PubMed]

112. Petrova, N.V.; Velichko, A.K.; Razin, S.V.; Kantidze, O.L. Small Molecule Compounds That Induce Cellular Senescence. Aging Cell 2016, 15, 999-1017. [CrossRef] [PubMed]

113. Malaquin, N.; Olivier, M.-A.; Martinez, A.; Nadeau, S.; Sawchyn, C.; Coppé, J.-P.; Cardin, G.; Mallette, F.A.; Campisi, J.; Rodier, F. Non-Canonical ATM/MRN Activities Temporally Define the Senescence Secretory Program. EMBO Rep. 2020, 21 , e50718. [CrossRef] [PubMed]

114. Bertran-Alamillo, J.; Cattan, V.; Schoumacher, M.; Codony-Servat, J.; Giménez-Capitán, A.; Cantero, F.; Burbridge, M.; Rodríguez, S.; Teixidó, C.; Roman, R.; et al. AURKB as a Target in Non-Small Cell Lung Cancer with Acquired Resistance to Anti-EGFR Therapy. Nat. Commun. 2019, 10, 1812. [CrossRef] [PubMed]

115. Wagner, V.; Gil, J. Senescence as a Therapeutically Relevant Response to CDK4/6 Inhibitors. Oncogene 2020, 39, 5165-5176. [CrossRef]

116. Kalathur, M.; Toso, A.; Chen, J.; Revandkar, A.; Danzer-Baltzer, C.; Guccini, I.; Alajati, A.; Sarti, M.; Pinton, S.; Brambilla, L.; et al. A Chemogenomic Screening Identifies CK2 as a Target for Pro-Senescence Therapy in PTEN-Deficient Tumours. Nat. Commun. 2015, 6, 7227. [CrossRef]

117. Fleury, H.; Malaquin, N.; Tu, V.; Gilbert, S.; Martinez, A.; Olivier, M.-A.; Sauriol, A.; Communal, L.; Leclerc-Desaulniers, K.; Carmona, E.; et al. Exploiting Interconnected Synthetic Lethal Interactions between PARP Inhibition and Cancer Cell Reversible Senescence. Nat. Commun. 2019, 10, 2556. [CrossRef]

118. Demaria, M.; O’Leary, M.N.; Chang, J.; Shao, L.; Liu, S.; Alimirah, F.; Koenig, K.; Le, C.; Mitin, N.; Deal, A.M.; et al. Cellular Senescence Promotes Adverse Effects of Chemotherapy and Cancer Relapse. Cancer Discov. 2017, 7, 165-176. [CrossRef] 
119. Saleh, T.; Tyutyunyk-Massey, L.; Gewirtz, D.A. Tumor Cell Escape from Therapy-Induced Senescence as a Model of Disease Recurrence after Dormancy. Cancer Res. 2019, 79, 1044-1046. [CrossRef]

120. Elmore, L.W.; Di, X.; Dumur, C.; Holt, S.E.; Gewirtz, D.A. Evasion of a Single-Step, Chemotherapy-Induced Senescence in Breast Cancer Cells: Implications for Treatment Response. Clin. Cancer Res. Off. J. Am. Assoc. Cancer Res. 2005, 11, 2637-2643. [CrossRef]

121. Chakradeo, S.; Elmore, L.W.; Gewirtz, D.A. Is Senescence Reversible? Curr. Drug Targets 2016, 17, 460-466. [CrossRef] [PubMed]

122. Eggert, T.; Wolter, K.; Ji, J.; Ma, C.; Yevsa, T.; Klotz, S.; Medina-Echeverz, J.; Longerich, T.; Forgues, M.; Reisinger, F.; et al. Distinct Functions of Senescence-Associated Immune Responses in Liver Tumor Surveillance and Tumor Progression. Cancer Cell 2016, 30, 533-547. [CrossRef] [PubMed]

123. Roberson, R.S.; Kussick, S.J.; Vallieres, E.; Chen, S.-Y.J.; Wu, D.Y. Escape from Therapy-Induced Accelerated Cellular Senescence in P53-Null Lung Cancer Cells and in Human Lung Cancers. Cancer Res. 2005, 65, 2795-2803. [CrossRef] [PubMed]

124. Yang, L.; Fang, J.; Chen, J. Tumor Cell Senescence Response Produces Aggressive Variants. Cell Death Discov. 2017,3 , 17049. [CrossRef] [PubMed]

125. Milanovic, M.; Fan, D.N.Y.; Belenki, D.; Däbritz, J.H.M.; Zhao, Z.; Yu, Y.; Dörr, J.R.; Dimitrova, L.; Lenze, D.; Monteiro Barbosa, I.A.; et al. Senescence-Associated Reprogramming Promotes Cancer Stemness. Nature 2018, 553, 96-100. [CrossRef] [PubMed]

126. Milanovic, M.; Yu, Y.; Schmitt, C.A. The Senescence-Stemness Alliance-A Cancer-Hijacked Regeneration Principle. Trends Cell Biol. 2018, 28, 1049-1061. [CrossRef]

127. Patel, P.L.; Suram, A.; Mirani, N.; Bischof, O.; Herbig, U. Derepression of HTERT Gene Expression Promotes Escape from Oncogene-Induced Cellular Senescence. Proc. Natl. Acad. Sci. USA 2016, 113, E5024-E5033. [CrossRef]

128. Ozturk, N.; Erdal, E.; Mumcuoglu, M.; Akcali, K.C.; Yalcin, O.; Senturk, S.; Arslan-Ergul, A.; Gur, B.; Yulug, I.; Cetin-Atalay, R.; et al. Reprogramming of Replicative Senescence in Hepatocellular Carcinoma-Derived Cells. Proc. Natl. Acad. Sci. USA 2006, 103, 2178-2183. [CrossRef]

129. Reyes, J.; Chen, J.-Y.; Stewart-Ornstein, J.; Karhohs, K.W.; Mock, C.S.; Lahav, G. Fluctuations in P53 Signaling Allow Escape from Cell-Cycle Arrest. Mol. Cell 2018, 71, 581-591.e5. [CrossRef]

130. Sieben, C.J.; Sturmlechner, I.; van de Sluis, B.; van Deursen, J.M. Two-Step Senescence-Focused Cancer Therapies. Trends Cell Biol. 2018, 28, 723-737. [CrossRef]

131. Childs, B.G.; Gluscevic, M.; Baker, D.J.; Laberge, R.-M.; Marquess, D.; Dananberg, J.; van Deursen, J.M. Senescent Cells: An Emerging Target for Diseases of Ageing. Nat. Rev. Drug Discov. 2017, 16, 718-735. [CrossRef] [PubMed]

132. von Kobbe, C. Targeting Senescent Cells: Approaches, Opportunities, Challenges. Aging 2019, 11, 12844-12861. [CrossRef] [PubMed]

133. Amaya-Montoya, M.; Pérez-Londoño, A.; Guatibonza-García, V.; Vargas-Villanueva, A.; Mendivil, C.O. Cellular Senescence as a Therapeutic Target for Age-Related Diseases: A Review. Adv. Ther. 2020, 37, 1407-1424. [CrossRef] [PubMed]

134. Ovadya, Y.; Krizhanovsky, V. Strategies Targeting Cellular Senescence. J. Clin. Invest. 2018, 128, 1247-1254. [CrossRef] [PubMed]

135. Lujambio, A. To Clear, or Not to Clear (Senescent Cells)? That Is the Question. BioEssays News Rev. Mol. Cell. Dev. Biol. 2016, 38 (Suppl. 1), S56-S64. [CrossRef] [PubMed]

136. Prata, L.G.P.L.; Ovsyannikova, I.G.; Tchkonia, T.; Kirkland, J.L. Senescent Cell Clearance by the Immune System: Emerging Therapeutic Opportunities. Semin. Immunol. 2018, 40, 101275. [CrossRef] [PubMed]

137. Saleh, T.; Tyutynuk-Massey, L.; Cudjoe, E.K.; Idowu, M.O.; Landry, J.W.; Gewirtz, D.A. Non-Cell Autonomous Effects of the Senescence-Associated Secretory Phenotype in Cancer Therapy. Front. Oncol. 2018, 8, 164. [CrossRef] [PubMed]

138. Dunn, G.P.; Bruce, A.T.; Ikeda, H.; Old, L.J.; Schreiber, R.D. Cancer Immunoediting: From Immunosurveillance to Tumor Escape. Nat. Immunol. 2002, 3, 991-998. [CrossRef]

139. Triana-Martínez, F.; Loza, M.I.; Domínguez, E. Beyond Tumor Suppression: Senescence in Cancer Stemness and Tumor Dormancy. Cells 2020, 9, 346. [CrossRef]

140. Ritschka, B.; Storer, M.; Mas, A.; Heinzmann, F.; Ortells, M.C.; Morton, J.P.; Sansom, O.J.; Zender, L.; Keyes, W.M. The SenescenceAssociated Secretory Phenotype Induces Cellular Plasticity and Tissue Regeneration. Genes Dev. 2017, 31, 172-183. [CrossRef]

141. Laberge, R.-M.; Zhou, L.; Sarantos, M.R.; Rodier, F.; Freund, A.; de Keizer, P.L.J.; Liu, S.; Demaria, M.; Cong, Y.-S.; Kapahi, P.; et al. Glucocorticoids Suppress Selected Components of the Senescence-Associated Secretory Phenotype. Aging Cell 2012, 11, 569-578. [CrossRef] [PubMed]

142. Fontana, L.; Nehme, J.; Demaria, M. Caloric Restriction and Cellular Senescence. Mech. Ageing Dev. 2018, 176, 19-23. [CrossRef] [PubMed]

143. Grabowska, W.; Sikora, E.; Bielak-Zmijewska, A. Sirtuins, a Promising Target in Slowing down the Ageing Process. Biogerontology 2017, 18, 447-476. [CrossRef] [PubMed]

144. de Magalhães, J.P.; Passos, J.F. Stress, Cell Senescence and Organismal Ageing. Mech. Ageing Dev. 2018, 170, 2-9. [CrossRef]

145. Kang, C.; Elledge, S.J. How Autophagy Both Activates and Inhibits Cellular Senescence. Autophagy 2016, 12, 898-899. [CrossRef]

146. Bjedov, I.; Toivonen, J.M.; Kerr, F.; Slack, C.; Jacobson, J.; Foley, A.; Partridge, L. Mechanisms of Life Span Extension by Rapamycin in the Fruit Fly Drosophila Melanogaster. Cell Metab. 2010, 11, 35-46. [CrossRef]

147. Miller, R.A.; Harrison, D.E.; Astle, C.M.; Fernandez, E.; Flurkey, K.; Han, M.; Javors, M.A.; Li, X.; Nadon, N.L.; Nelson, J.F.; et al. Rapamycin-Mediated Lifespan Increase in Mice Is Dose and Sex Dependent and Metabolically Distinct from Dietary Restriction. Aging Cell 2014, 13, 468-477. [CrossRef] 
148. Harrison, D.E.; Strong, R.; Sharp, Z.D.; Nelson, J.F.; Astle, C.M.; Flurkey, K.; Nadon, N.L.; Wilkinson, J.E.; Frenkel, K.; Carter, C.S.; et al. Rapamycin Fed Late in Life Extends Lifespan in Genetically Heterogeneous Mice. Nature 2009, 460, 392-395. [CrossRef]

149. Wang, R.; Yu, Z.; Sunchu, B.; Shoaf, J.; Dang, I.; Zhao, S.; Caples, K.; Bradley, L.; Beaver, L.M.; Ho, E.; et al. Rapamycin Inhibits the Secretory Phenotype of Senescent Cells by a Nrf2-Independent Mechanism. Aging Cell 2017, 16, 564-574. [CrossRef]

150. Laberge, R.-M.; Sun, Y.; Orjalo, A.V.; Patil, C.K.; Freund, A.; Zhou, L.; Curran, S.C.; Davalos, A.R.; Wilson-Edell, K.A.; Liu, S.; et al MTOR Regulates the Pro-Tumorigenic Senescence-Associated Secretory Phenotype by Promoting IL1A Translation. Nat. Cell Biol. 2015, 17, 1049-1061. [CrossRef]

151. Alimbetov, D.; Davis, T.; Brook, A.J.C.; Cox, L.S.; Faragher, R.G.A.; Nurgozhin, T.; Zhumadilov, Z.; Kipling, D. Suppression of the Senescence-Associated Secretory Phenotype (SASP) in Human Fibroblasts Using Small Molecule Inhibitors of P38 MAP Kinase and MK2. Biogerontology 2016, 17, 305-315. [CrossRef] [PubMed]

152. Kang, H.T.; Park, J.T.; Choi, K.; Kim, Y.; Choi, H.J.C.; Jung, C.W.; Lee, Y.-S.; Park, S.C. Chemical Screening Identifies ATM as a Target for Alleviating Senescence. Nat. Chem. Biol. 2017, 13, 616-623. [CrossRef] [PubMed]

153. Zhao, J.; Zhang, L.; Lu, A.; Han, Y.; Colangelo, D.; Bukata, C.; Scibetta, A.; Yousefzadeh, M.J.; Li, X.; Gurkar, A.U.; et al. ATM Is a Key Driver of NF-KB-Dependent DNA-Damage-Induced Senescence, Stem Cell Dysfunction and Aging. Aging 2020, 12, 4688-4710. [CrossRef] [PubMed]

154. Zhang, B.; Fu, D.; Xu, Q.; Cong, X.; Wu, C.; Zhong, X.; Ma, Y.; Lv, Z.; Chen, F.; Han, L.; et al. The Senescence-Associated Secretory Phenotype Is Potentiated by Feedforward Regulatory Mechanisms Involving Zscan4 and TAK1. Nat. Commun. 2018, 9, 1723. [CrossRef]

155. Camorani, S.; Cerchia, L.; Fedele, M.; Erba, E.; D'Incalci, M.; Crescenzi, E. Trabectedin Modulates the Senescence-Associated Secretory Phenotype and Promotes Cell Death in Senescent Tumor Cells by Targeting NF-KB. Oncotarget 2018, 9, 19929-19944. [CrossRef] [PubMed]

156. Kasznicki, J.; Sliwinska, A.; Drzewoski, J. Metformin in Cancer Prevention and Therapy. Ann. Transl. Med. 2014, 2, 57. [CrossRef]

157. Saraei, P.; Asadi, I.; Kakar, M.A.; Moradi-Kor, N. The Beneficial Effects of Metformin on Cancer Prevention and Therapy: A Comprehensive Review of Recent Advances. Cancer Manag. Res. 2019, 11, 3295-3313. [CrossRef]

158. Bailey, C.J.; Turner, R.C. Metformin. N. Engl. J. Med. 1996, 334, 574-579. [CrossRef]

159. Kulkarni, A.S.; Gubbi, S.; Barzilai, N. Benefits of Metformin in Attenuating the Hallmarks of Aging. Cell Metab. 2020, 32, 15-30. [CrossRef]

160. Hu, Q.; Peng, J.; Jiang, L.; Li, W.; Su, Q.; Zhang, J.; Li, H.; Song, M.; Cheng, B.; Xia, J.; et al. Metformin as a Senostatic Drug Enhances the Anticancer Efficacy of CDK4/6 Inhibitor in Head and Neck Squamous Cell Carcinoma. Cell Death Dis. 2020, 11, 925. [CrossRef]

161. Soto-Gamez, A.; Demaria, M. Therapeutic Interventions for Aging: The Case of Cellular Senescence. Drug Discov. Today 2017, 22, 786-795. [CrossRef] [PubMed]

162. Moiseeva, O.; Deschênes-Simard, X.; St-Germain, E.; Igelmann, S.; Huot, G.; Cadar, A.E.; Bourdeau, V.; Pollak, M.N.; Ferbeyre, G. Metformin Inhibits the Senescence-Associated Secretory Phenotype by Interfering with IKK/NF-KB Activation. Aging Cell 2013, 12, 489-498. [CrossRef] [PubMed]

163. Bian, Y.; Wei, J.; Zhao, C.; Li, G. Natural Polyphenols Targeting Senescence: A Novel Prevention and Therapy Strategy for Cancer. Int. J. Mol. Sci. 2020, 21, 684. [CrossRef] [PubMed]

164. Velarde, M.C.; Demaria, M. Targeting Senescent Cells: Possible Implications for Delaying Skin Aging: A Mini-Review. Gerontology 2016, 62, 513-518. [CrossRef]

165. Perrott, K.M.; Wiley, C.D.; Desprez, P.-Y.; Campisi, J. Apigenin Suppresses the Senescence-Associated Secretory Phenotype and Paracrine Effects on Breast Cancer Cells. GeroScience 2017, 39, 161-173. [CrossRef]

166. Lim, H.; Park, H.; Kim, H.P. Effects of Flavonoids on Senescence-Associated Secretory Phenotype Formation from BleomycinInduced Senescence in BJ Fibroblasts. Biochem. Pharmacol. 2015, 96, 337-348. [CrossRef]

167. Chen, G.Y.; Nuñez, G. Sterile Inflammation: Sensing and Reacting to Damage. Nat. Rev. Immunol. 2010, 10, 826-837. [CrossRef]

168. Xu, M.; Tchkonia, T.; Ding, H.; Ogrodnik, M.; Lubbers, E.R.; Pirtskhalava, T.; White, T.A.; Johnson, K.O.; Stout, M.B.; Mezera, V.; et al. JAK Inhibition Alleviates the Cellular Senescence-Associated Secretory Phenotype and Frailty in Old Age. Proc. Natl. Acad. Sci. USA 2015, 112, E6301-E6310. [CrossRef]

169. Griveau, A.; Wiel, C.; Ziegler, D.V.; Bergo, M.O.; Bernard, D. The JAK1/2 Inhibitor Ruxolitinib Delays Premature Aging Phenotypes. Aging Cell 2020, 19, e13122. [CrossRef]

170. Rikitake, Y.; Liao, J.K. Rho GTPases, Statins, and Nitric Oxide. Circ. Res. 2005, 97, 1232-1235. [CrossRef]

171. Liu, S.; Uppal, H.; Demaria, M.; Desprez, P.-Y.; Campisi, J.; Kapahi, P. Simvastatin Suppresses Breast Cancer Cell Proliferation Induced by Senescent Cells. Sci. Rep. 2015, 5, 17895. [CrossRef] [PubMed]

172. Fuhrmann-Stroissnigg, H.; Ling, Y.Y.; Zhao, J.; McGowan, S.J.; Zhu, Y.; Brooks, R.W.; Grassi, D.; Gregg, S.Q.; Stripay, J.L.; Dorronsoro, A.; et al. Identification of HSP90 Inhibitors as a Novel Class of Senolytics. Nat. Commun. 2017, 8, 422. [CrossRef] [PubMed]

173. Watanabe, S.; Kawamoto, S.; Ohtani, N.; Hara, E. Impact of Senescence-Associated Secretory Phenotype and Its Potential as a Therapeutic Target for Senescence-Associated Diseases. Cancer Sci. 2017, 108, 563-569. [CrossRef] [PubMed]

174. Lau, L.; Porciuncula, A.; Yu, A.; Iwakura, Y.; David, G. Uncoupling the Senescence-Associated Secretory Phenotype from Cell Cycle Exit via Interleukin-1 Inactivation Unveils Its Protumorigenic Role. Mol. Cell. Biol. 2019, 39. [CrossRef] [PubMed] 
175. Prattichizzo, F.; De Nigris, V.; La Sala, L.; Procopio, A.D.; Olivieri, F.; Ceriello, A. "Inflammaging" as a Druggable Target: A Senescence-Associated Secretory Phenotype-Centered View of Type 2 Diabetes. Oxid. Med. Cell. Longev. 2016, 2016, 1810327. [CrossRef]

176. Prattichizzo, F.; Giuliani, A.; Recchioni, R.; Bonafè, M.; Marcheselli, F.; De Carolis, S.; Campanati, A.; Giuliodori, K.; Rippo, M.R.; Brugè, F.; et al. Anti-TNF- $\alpha$ Treatment Modulates SASP and SASP-Related MicroRNAs in Endothelial Cells and in Circulating Angiogenic Cells. Oncotarget 2016, 7, 11945-11958. [CrossRef]

177. Kirkland, J.L.; Tchkonia, T. Cellular Senescence: A Translational Perspective. EBioMedicine 2017, 21, 21-28. [CrossRef]

178. Myrianthopoulos, V.; Evangelou, K.; Vasileiou, P.V.S.; Cooks, T.; Vassilakopoulos, T.P.; Pangalis, G.A.; Kouloukoussa, M.; Kittas, C.; Georgakilas, A.G.; Gorgoulis, V.G. Senescence and Senotherapeutics: A New Field in Cancer Therapy. Pharmacol. Ther. 2019, 193, 31-49. [CrossRef]

179. Kirkland, J.L.; Tchkonia, T.; Zhu, Y.; Niedernhofer, L.J.; Robbins, P.D. The Clinical Potential of Senolytic Drugs. J. Am. Geriatr. Soc. 2017, 65, 2297-2301. [CrossRef]

180. Hickson, L.J.; Langhi Prata, L.G.P.; Bobart, S.A.; Evans, T.K.; Giorgadze, N.; Hashmi, S.K.; Herrmann, S.M.; Jensen, M.D.; Jia, Q.; Jordan, K.L.; et al. Senolytics Decrease Senescent Cells in Humans: Preliminary Report from a Clinical Trial of Dasatinib plus Quercetin in Individuals with Diabetic Kidney Disease. EBioMedicine 2019, 47, 446-456. [CrossRef]

181. Farr, J.N.; Xu, M.; Weivoda, M.M.; Monroe, D.G.; Fraser, D.G.; Onken, J.L.; Negley, B.A.; Sfeir, J.G.; Ogrodnik, M.B.; Hachfeld, C.M.; et al. Targeting Cellular Senescence Prevents Age-Related Bone Loss in Mice. Nat. Med. 2017, 23, 1072-1079. [CrossRef] [PubMed]

182. Ogrodnik, M.; Miwa, S.; Tchkonia, T.; Tiniakos, D.; Wilson, C.L.; Lahat, A.; Day, C.P.; Burt, A.; Palmer, A.; Anstee, Q.M.; et al. Cellular Senescence Drives Age-Dependent Hepatic Steatosis. Nat. Commun. 2017, 8, 15691. [CrossRef] [PubMed]

183. Xu, M.; Pirtskhalava, T.; Farr, J.N.; Weigand, B.M.; Palmer, A.K.; Weivoda, M.M.; Inman, C.L.; Ogrodnik, M.B.; Hachfeld, C.M.; Fraser, D.G.; et al. Senolytics Improve Physical Function and Increase Lifespan in Old Age. Nat. Med. 2018, 24, 1246-1256. [CrossRef]

184. Schafer, M.J.; White, T.A.; Iijima, K.; Haak, A.J.; Ligresti, G.; Atkinson, E.J.; Oberg, A.L.; Birch, J.; Salmonowicz, H.; Zhu, Y.; et al. Cellular Senescence Mediates Fibrotic Pulmonary Disease. Nat. Commun. 2017, 8, 14532. [CrossRef]

185. Justice, J.N.; Nambiar, A.M.; Tchkonia, T.; LeBrasseur, N.K.; Pascual, R.; Hashmi, S.K.; Prata, L.; Masternak, M.M.; Kritchevsky, S.B.; Musi, N.; et al. Senolytics in Idiopathic Pulmonary Fibrosis: Results from a First-in-Human, Open-Label, Pilot Study. EBioMedicine 2019, 40, 554-563. [CrossRef]

186. Chang, J.; Wang, Y.; Shao, L.; Laberge, R.-M.; Demaria, M.; Campisi, J.; Janakiraman, K.; Sharpless, N.E.; Ding, S.; Feng, W.; et al. Clearance of Senescent Cells by ABT263 Rejuvenates Aged Hematopoietic Stem Cells in Mice. Nat. Med. 2016, 22, 78-83. [CrossRef]

187. Shahbandi, A.; Rao, S.G.; Anderson, A.Y.; Frey, W.D.; Olayiwola, J.O.; Ungerleider, N.A.; Jackson, J.G. BH3 Mimetics Selectively Eliminate Chemotherapy-Induced Senescent Cells and Improve Response in TP53 Wild-Type Breast Cancer. Cell Death Differ. 2020, 27, 3097-3116. [CrossRef]

188. Zhu, Y.; Tchkonia, T.; Fuhrmann-Stroissnigg, H.; Dai, H.M.; Ling, Y.Y.; Stout, M.B.; Pirtskhalava, T.; Giorgadze, N.; Johnson, K.O.; Giles, C.B.; et al. Identification of a Novel Senolytic Agent, Navitoclax, Targeting the Bcl-2 Family of Anti-Apoptotic Factors. Aging Cell 2016, 15, 428-435. [CrossRef]

189. Ritschka, B.; Knauer-Meyer, T.; Gonçalves, D.S.; Mas, A.; Plassat, J.-L.; Durik, M.; Jacobs, H.; Pedone, E.; Di Vicino, U.; Cosma, M.P.; et al. The Senotherapeutic Drug ABT-737 Disrupts Aberrant P21 Expression to Restore Liver Regeneration in Adult Mice. Genes Dev. 2020, 34, 489-494. [CrossRef]

190. Yosef, R.; Pilpel, N.; Tokarsky-Amiel, R.; Biran, A.; Ovadya, Y.; Cohen, S.; Vadai, E.; Dassa, L.; Shahar, E.; Condiotti, R.; et al. Directed Elimination of Senescent Cells by Inhibition of BCL-W and BCL-XL. Nat. Commun. 2016, 7, 11190. [CrossRef]

191. He, Y.; Zhang, X.; Chang, J.; Kim, H.-N.; Zhang, P.; Wang, Y.; Khan, S.; Liu, X.; Zhang, X.; Lv, D.; et al. Using Proteolysis-Targeting Chimera Technology to Reduce Navitoclax Platelet Toxicity and Improve Its Senolytic Activity. Nat. Commun. 2020, 11, 1996. [CrossRef] [PubMed]

192. Zhu, Y.; Doornebal, E.J.; Pirtskhalava, T.; Giorgadze, N.; Wentworth, M.; Fuhrmann-Stroissnigg, H.; Niedernhofer, L.J.; Robbins, P.D.; Tchkonia, T.; Kirkland, J.L. New Agents That Target Senescent Cells: The Flavone, Fisetin, and the BCL-XL Inhibitors, A1331852 and A1155463. Aging 2017, 9, 955-963. [CrossRef] [PubMed]

193. Yang, P.-M.; Tseng, H.-H.; Peng, C.-W.; Chen, W.-S.; Chiu, S.-J. Dietary Flavonoid Fisetin Targets Caspase-3-Deficient Human Breast Cancer MCF-7 Cells by Induction of Caspase-7-Associated Apoptosis and Inhibition of Autophagy. Int. J. Oncol. 2012, 40, 469-478. [CrossRef] [PubMed]

194. Youns, M.; Abdel Halim Hegazy, W. The Natural Flavonoid Fisetin Inhibits Cellular Proliferation of Hepatic, Colorectal, and Pancreatic Cancer Cells through Modulation of Multiple Signaling Pathways. PLoS ONE 2017, 12, e0169335. [CrossRef]

195. Chen, Y.-C.; Shen, S.-C.; Lee, W.-R.; Lin, H.-Y.; Ko, C.-H.; Shih, C.-M.; Yang, L.-L. Wogonin and Fisetin Induction of Apoptosis through Activation of Caspase 3 Cascade and Alternative Expression of P21 Protein in Hepatocellular Carcinoma Cells SK-HEP-1. Arch. Toxicol. 2002, 76, 351-359. [CrossRef]

196. Cho, H.-J.; Yang, E.J.; Park, J.T.; Kim, J.-R.; Kim, E.-C.; Jung, K.-J.; Park, S.C.; Lee, Y.-S. Identification of SYK Inhibitor, R406 as a Novel Senolytic Agent. Aging 2020, 12, 8221-8240. [CrossRef] 
197. Fuhrmann-Stroissnigg, H.; Niedernhofer, L.J.; Robbins, P.D. Hsp90 Inhibitors as Senolytic Drugs to Extend Healthy Aging. Cell Cycle Georget. Tex 2018, 17, 1048-1055. [CrossRef]

198. Verzella, D.; Pescatore, A.; Capece, D.; Vecchiotti, D.; Ursini, M.V.; Franzoso, G.; Alesse, E.; Zazzeroni, F. Life, Death, and Autophagy in Cancer: NF-KB Turns up Everywhere. Cell Death Dis. 2020, 11, 210. [CrossRef]

199. Pungsrinont, T.; Sutter, M.F.; Ertingshausen, M.C.C.M.; Lakshmana, G.; Kokal, M.; Khan, A.S.; Baniahmad, A. Senolytic Compounds Control a Distinct Fate of Androgen Receptor Agonist- and Antagonist-Induced Cellular Senescent LNCaP Prostate Cancer Cells. Cell Biosci. 2020, 10, 59. [CrossRef]

200. Liu, Z.; Shi, Z.; Lin, J.; Zhao, S.; Hao, M.; Xu, J.; Li, Y.; Zhao, Q.; Tao, L.; Diao, A. Piperlongumine-Induced Nuclear Translocation of the FOXO3A Transcription Factor Triggers BIM-Mediated Apoptosis in Cancer Cells. Biochem. Pharmacol. 2019, 163, 101-110. [CrossRef]

201. Liu, X.; Wang, Y.; Zhang, X.; Gao, Z.; Zhang, S.; Shi, P.; Zhang, X.; Song, L.; Hendrickson, H.; Zhou, D.; et al. Senolytic Activity of Piperlongumine Analogues: Synthesis and Biological Evaluation. Bioorg. Med. Chem. 2018, 26, 3925-3938. [CrossRef] [PubMed]

202. Makhov, P.; Golovine, K.; Teper, E.; Kutikov, A.; Mehrazin, R.; Corcoran, A.; Tulin, A.; Uzzo, R.G.; Kolenko, V.M. Piperlongumine Promotes Autophagy via Inhibition of Akt/MTOR Signalling and Mediates Cancer Cell Death. Br. J. Cancer 2014, 110, 899-907. [CrossRef] [PubMed]

203. Zhang, X.; Zhang, S.; Liu, X.; Wang, Y.; Chang, J.; Zhang, X.; Mackintosh, S.G.; Tackett, A.J.; He, Y.; Lv, D.; et al. Oxidation Resistance 1 Is a Novel Senolytic Target. Aging Cell 2018, 17, e12780. [CrossRef]

204. Wang, Y.; Chang, J.; Liu, X.; Zhang, X.; Zhang, S.; Zhang, X.; Zhou, D.; Zheng, G. Discovery of Piperlongumine as a Potential Novel Lead for the Development of Senolytic Agents. Aging 2016, 8, 2915-2926. [CrossRef] [PubMed]

205. Samaraweera, L.; Adomako, A.; Rodriguez-Gabin, A.; McDaid, H.M. A Novel Indication for Panobinostat as a Senolytic Drug in NSCLC and HNSCC. Sci. Rep. 2017, 7, 1900. [CrossRef]

206. He, Y.; Li, W.; Lv, D.; Zhang, X.; Zhang, X.; Ortiz, Y.T.; Budamagunta, V.; Campisi, J.; Zheng, G.; Zhou, D. Inhibition of USP7 Activity Selectively Eliminates Senescent Cells in Part via Restoration of P53 Activity. Aging Cell 2020, 19, e13117. [CrossRef]

207. Vilgelm, A.E.; Pawlikowski, J.S.; Liu, Y.; Hawkins, O.E.; Davis, T.A.; Smith, J.; Weller, K.P.; Horton, L.W.; McClain, C.M.; Ayers, G.D.; et al. Mdm2 and Aurora Kinase a Inhibitors Synergize to Block Melanoma Growth by Driving Apoptosis and Immune Clearance of Tumor Cells. Cancer Res. 2015, 75, 181-193. [CrossRef]

208. Huang, H.; Tindall, D.J. Dynamic FoxO Transcription Factors. J. Cell Sci. 2007, 120, 2479-2487. [CrossRef]

209. Greer, E.L.; Brunet, A. FOXO Transcription Factors at the Interface between Longevity and Tumor Suppression. Oncogene 2005, 24, 7410-7425. [CrossRef]

210. Bourgeois, B.; Madl, T. Regulation of Cellular Senescence via the FOXO4-P53 Axis. FEBS Lett. 2018, 592, 2083-2097. [CrossRef]

211. Baar, M.P.; Brandt, R.M.C.; Putavet, D.A.; Klein, J.D.D.; Derks, K.W.J.; Bourgeois, B.R.M.; Stryeck, S.; Rijksen, Y.; van Willigenburg, H.; Feijtel, D.A.; et al. Targeted Apoptosis of Senescent Cells Restores Tissue Homeostasis in Response to Chemotoxicity and Aging. Cell 2017, 169, 132-147.e16. [CrossRef] [PubMed]

212. Dörr, J.R.; Yu, Y.; Milanovic, M.; Beuster, G.; Zasada, C.; Däbritz, J.H.M.; Lisec, J.; Lenze, D.; Gerhardt, A.; Schleicher, K.; et al. Synthetic Lethal Metabolic Targeting of Cellular Senescence in Cancer Therapy. Nature 2013, 501, 421-425. [CrossRef] [PubMed]

213. Wakita, M.; Takahashi, A.; Sano, O.; Loo, T.M.; Imai, Y.; Narukawa, M.; Iwata, H.; Matsudaira, T.; Kawamoto, S.; Ohtani, N.; et al. A BET Family Protein Degrader Provokes Senolysis by Targeting NHEJ and Autophagy in Senescent Cells. Nat. Commun. 2020, 11, 1935. [CrossRef] [PubMed]

214. Dostanic-Larson, I.; Van Huysse, J.W.; Lorenz, J.N.; Lingrel, J.B. The Highly Conserved Cardiac Glycoside Binding Site of Na,K-ATPase Plays a Role in Blood Pressure Regulation. Proc. Natl. Acad. Sci. USA 2005, 102, 15845-15850. [CrossRef]

215. Seema Patel Plant-Derived Cardiac Glycosides: Role in Heart Ailments and Cancer Management. Biomed. Pharmacother. Biomed. Pharmacother. 2016, 84, 1036-1041. [CrossRef]

216. Triana-Martínez, F.; Picallos-Rabina, P.; Da Silva-Álvarez, S.; Pietrocola, F.; Llanos, S.; Rodilla, V.; Soprano, E.; Pedrosa, P.; Ferreirós, A.; Barradas, M.; et al. Identification and Characterization of Cardiac Glycosides as Senolytic Compounds. Nat. Commun. 2019, 10, 4731. [CrossRef]

217. Guerrero, A.; Herranz, N.; Sun, B.; Wagner, V.; Gallage, S.; Guiho, R.; Wolter, K.; Pombo, J.; Irvine, E.E.; Innes, A.J.; et al. Cardiac Glycosides Are Broad-Spectrum Senolytics. Nat. Metab. 2019, 1, 1074-1088. [CrossRef]

218. Muñoz-Espín, D.; Rovira, M.; Galiana, I.; Giménez, C.; Lozano-Torres, B.; Paez-Ribes, M.; Llanos, S.; Chaib, S.; Muñoz-Martín, M.; Ucero, A.C.; et al. A Versatile Drug Delivery System Targeting Senescent Cells. EMBO Mol. Med. 2018, 10. [CrossRef]

219. Galiana, I.; Lozano-Torres, B.; Sancho, M.; Alfonso, M.; Bernardos, A.; Bisbal, V.; Serrano, M.; Martínez-Máñez, R.; Orzáez, M. Preclinical Antitumor Efficacy of Senescence-Inducing Chemotherapy Combined with a NanoSenolytic. J. Control. Release Off. J. Control. Release Soc. 2020, 323, 624-634. [CrossRef]

220. González-Gualda, E.; Pàez-Ribes, M.; Lozano-Torres, B.; Macias, D.; Wilson, J.R.; González-López, C.; Ou, H.-L.; Mirón-Barroso, S.; Zhang, Z.; Lérida-Viso, A.; et al. Galacto-Conjugation of Navitoclax as an Efficient Strategy to Increase Senolytic Specificity and Reduce Platelet Toxicity. Aging Cell 2020, 19, e13142. [CrossRef]

221. Ekpenyong-Akiba, A.E.; Canfarotta, F.; Abd, H.B.; Poblocka, M.; Casulleras, M.; Castilla-Vallmanya, L.; Kocsis-Fodor, G.; Kelly, M.E.; Janus, J.; Althubiti, M.; et al. Detecting and Targeting Senescent Cells Using Molecularly Imprinted Nanoparticles. Nanoscale Horiz. 2019, 4, 757-768. [CrossRef] 
222. Ke, S.; Lai, Y.; Zhou, T.; Li, L.; Wang, Y.; Ren, L.; Ye, S. Molybdenum Disulfide Nanoparticles Resist Oxidative Stress-Mediated Impairment of Autophagic Flux and Mitigate Endothelial Cell Senescence and Angiogenic Dysfunctions. ACS Biomater. Sci. Eng. 2018, 4, 663-674. [CrossRef] [PubMed]

223. Thapa, R.K.; Nguyen, H.T.; Jeong, J.-H.; Kim, J.R.; Choi, H.-G.; Yong, C.S.; Kim, J.O. Progressive Slowdown/Prevention of Cellular Senescence by CD9-Targeted Delivery of Rapamycin Using Lactose-Wrapped Calcium Carbonate Nanoparticles. Sci. Rep. 2017, 7, 43299. [CrossRef] [PubMed]

224. Lozano-Torres, B.; Blandez, J.F.; Sancenón, F.; Martínez-Máñez, R. Novel Probes and Carriers to Target Senescent Cells. In Senolytics in Disease, Ageing and Longevity; Muñoz-Espin, D., Demaria, M., Eds.; Healthy Ageing and Longevity; Springer International Publishing: Cham, Switzerland, 2020; Volume 11, pp. 163-180. ISBN 978-3-030-44902-5.

225. Guerrero, A.; Guiho, R.; Herranz, N.; Uren, A.; Withers, D.J.; Martínez-Barbera, J.P.; Tietze, L.F.; Gil, J. Galactose-Modified Duocarmycin Prodrugs as Senolytics. Aging Cell 2020, 19, e13133. [CrossRef] [PubMed]

226. Cai, Y.; Zhou, H.; Zhu, Y.; Sun, Q.; Ji, Y.; Xue, A.; Wang, Y.; Chen, W.; Yu, X.; Wang, L.; et al. Elimination of Senescent Cells by $\beta$-Galactosidase-Targeted Prodrug Attenuates Inflammation and Restores Physical Function in Aged Mice. Cell Res. 2020, 30, 574-589. [CrossRef] [PubMed] 